\title{
Influences of Chemical Functionalities on Crystal Structures and Electrochemical Properties of Dihydro-benzoxazine Dimer Derivatives
}

\author{
Natapol Suetrong ${ }^{1}$, Kantapat Chansaenpak ${ }^{2}$, Sarawoot Impeng ${ }^{2} \mathbb{D}$, Piyanut Pinyou ${ }^{3} \mathbb{D}$, Vincent Blay $^{4}$, \\ Rubén Blay-Roger ${ }^{5}$, Sireerat Lisnund ${ }^{6}$, Pongsakorn Kanjanaboos ${ }^{7} \mathbb{D}$, Yuranan Hanlumyuang ${ }^{1}$, \\ Suttipong Wannapaiboon ${ }^{8, *(\mathbb{D})}$ and Worawat Wattanathana ${ }^{1, * \text { (D) }}$
}

1 Department of Materials Engineering, Faculty of Engineering, Kasetsart University, Bangkok 10900, Thailand; natapol.s@ku.th (N.S.); yuranan.h@ku.th (Y.H.)

2 National Nanotechnology Center, National Science and Technology Development Agency, Thailand Science Park, Khlong Nueng 12120, Thailand; kantapat.cha@nanotec.or.th (K.C.); sarawoot.imp@nanotec.or.th (S.I.)

3 School of Chemistry, Institute of Science, Suranaree University of Technology, 111 University Avenue, Nakhon Ratchasima 30000, Thailand; piyanutp@sut.ac.th

4 Department of Microbiology and Environmental Toxicology, University of California Santa Cruz, Santa Cruz, CA 95064, USA; vroger@ucsc.edu

5 Instituto de Ciencia Molecular, Universitat de València, Catedrático José Beltrán 2, 46980 Paterna, Spain; joblayro@alumni.uv.es

6 Department of Applied Chemistry, Faculty of Science and Liberal Arts, Rajamangala University of Technology Isan, 744, Suranarai Rd., Nakhon Ratchasima 30000, Thailand; sireerat.in@rmuti.ac.th

check for updates

Citation: Suetrong, N.; Chansaenpak, K.; Impeng, S.; Pinyou, P.; Blay, V.; Blay-Roger, R.; Lisnund, S.; Kanjanaboos, P.; Hanlumyuang, Y.; Wannapaiboon, S.; et al. Influences of Chemical Functionalities on Crystal Structures and Electrochemical Properties of Dihydro-benzoxazine Dimer Derivatives. Crystals 2021, 11, 979. https://doi.org/10.3390/ cryst11080979

Received: 30 June 2021

Accepted: 17 August 2021

Published: 18 August 2021

Publisher's Note: MDPI stays neutral with regard to jurisdictional claims in published maps and institutional affiliations.

Copyright: (c) 2021 by the authors. Licensee MDPI, Basel, Switzerland. This article is an open access article distributed under the terms and conditions of the Creative Commons Attribution (CC BY) license (https:// creativecommons.org/licenses/by/ $4.0 /)$.
7 School of Materials Science and Innovation, Faculty of Science, Mahidol University, Bangkok 10400, Thailand; pongsakorn.kan@mahidol.edu

8 Synchrotron Light Research Institute, 111 University Avenue, Nakhon Ratchasima 30000, Thailand

* Correspondence: suttipong@slri.or.th (S.W.); fengwwwa@ku.ac.th (W.W.)

Abstract: Dihydro-1,3,2H-benzoxazine dimer derivatives or dihydro-benzoxazine dimers are a class of compounds typically prepared by ring-opening reactions between dihydro-benzoxazines and phenols. Dihydro-benzoxazine dimers act as chelating agents for several transition and rare-earth cations. To better understand the chelating properties, it is necessary to examine their structural features and electrochemical characteristics thoroughly. However, the electrochemical properties of dihydro-benzoxazine dimers have not been tremendously examined. Herein, eight derivatives of dihydro-benzoxazine dimers possessing different substituents on the benzene ring and the tertiaryamine nitrogen were synthesized as model compounds to investigate their influences on crystal structures and electrochemical properties. The crystal structure of the dihydro-benzoxazine dimer, namely 2,2'-(cyclohexylazanediyl)bis(methylene)bis(4-methoxyphenol) (7), is identified for the first time and further used to compare with the crystal structures of other derivatives reported previously. For all the derivatives, intermolecular $\mathrm{O}-\mathrm{H} \cdots \mathrm{O}$ hydrogen bonds are the significant interactions to hold the crystal packing of (7) and also the other derivatives. Hirshfeld surface analyses confirm the presence of intermolecular $\mathrm{O}-\mathrm{H}$... O hydrogen bonds. Redox behavior of the eight dihydrobenzoxazine dimers was studied by cyclic voltammetry. An oxidation peak observed at $0.25-0.47 \mathrm{~V}$ corresponds to the oxidation of the phenolic $-\mathrm{OH}$ group to the phenoxonium intermediate. The shift in the electrochemical peak positions is due to the different abilities of the substituents to stabilize the phenoxonium cation intermediate. The stabilizing power is ranged in the following order: methoxy $>$ dimethyl $>$ ethyl $\approx$ methyl, and N-cyclohexyl $>$ N-methyl. Thus, the derivative (7), which contains both the methoxy and $\mathrm{N}$-cyclohexyl groups, has the lowest oxidation potential. Our work elucidates the effect of the substituents on the crystal structures and electrochemical properties of the dihydro-benzoxazine dimers.

Keywords: crystal structure; Hirshfeld surface; electrochemical property; benzoxazine 


\section{Introduction}

Dihydro-benzoxazines are small molecules containing a benzene ring fused with a dihydro-oxazine heterocyclic ring. Among the different isomers of dihydro-benzoxazines, only dihydro-1,3,2H-benzoxazines can polymerize through a ring-opening polymerization forming polybenzoxazines, so they are usually called "benzoxazine monomers". The one-pot Mannich reaction of phenols, primary amines, and formaldehyde is the most common route to synthesize dihydro-benzoxazines [1,2]. The ability to vary the starting materials brings about the structural diversity of this class of compounds. This enables researchers to fabricate functional benzoxazine monomers as well as polybenzoxazines with a broad spectrum of properties, such as near-zero shrinkage upon polymerization [3-6], high chemical and thermal stabilities [7-14], desirable mechanical strengths [14,15], low flammability [16,17], low water absorption [18], good dielectric properties [19-22], and high anti-corrosion performances [23-28]. A variety of polymerization conditions (e.g., temperatures, reaction periods, and initiators) have also been investigated to produce polybenzoxazines with even better properties. Surprisingly, the attempt of using phenols as initiators for the polymerization of dihydro-benzoxazines to create polybenzoxazines was not successful [29]. The progressive reactions are terminated by the formation of the intramolecular hydrogen bonds in the molecules of the adducts according to the ringopening reaction of dihydro-benzoxazines and phenols. These products are then named dihydro-benzoxazine dimers [29].

A particularly interesting structural feature of dihydro-benzoxazine dimers is the aza-bis(methylene)-bis(phenol) moiety, which is typically generated from the ring-opening polymerization reaction. The aza-methylene-phenol group is the repeating unit in polybenzoxazines. Therefore, dihydro-benzoxazine dimers are often used as simplified models for studying the properties of polybenzoxazines [30]. A detailed understanding of the interactions between the dihydro-benzoxazine dimers (and/or polybenzoxazines) themselves within their crystal structures and the ones with other molecules (or ions) is essential for the development of new materials with improved properties. Particularly, it can formulate better additives for composite materials, which are applicable as the major use of polybenzoxazines [2,31-33]. Apart from their use as the models of polybenzoxazines due to their structural similarity, dihydro-benzoxazine dimers are also utilized in many different areas, such as the starting materials to synthesize cyclic derivatives with ion-extracting properties [34,35], the pendant groups for thermochromic polymers [36], and even as agents for lung cancer treatment $[37,38]$. Moreover, dihydro-benzoxazine dimers with two oxygen and one nitrogen atoms may serve as ligands for various metal ions since different coordination geometries (monodentate, bidentate, and tridentate coordination modes) may be found $[39,40]$. This might extend the application range of dihydro-benzoxazine dimers to other fields, such as catalysis [41-43], luminescence [44], medical applications [45,46], and pollutant removal $[43,47]$. To gain insights into their chelating abilities, understanding their chemical functionalities, crystal structures, and electrochemical properties can be helpful. Although some crystal structures have been reported, the electrochemical properties of dihydro-benzoxazine dimers have not been systematically investigated.

In this work, we report the synthesis of eight dihydro-benzoxazine dimers varying the substituents on the phenol rings and the tertiary amine. The substituents on the phenol rings include methyl, ethyl, methoxy, and dimethyl groups, while the Nsubstituents include methyl and cyclohexyl groups. The crystal structure of one of the dihydro-benzoxazine dimers (namely (7)) is reported for the first time and compared with other reported structures. The resemble intra- and intermolecular interactions within the crystals of dihydro-benzoxazine dimer derivatives have been revealed. Hirshfeld surfaces have been computed to confirm the presence of intermolecular interactions. The influence of the chemical functionality of substituents on electrochemical properties has been investigated and explained in detail. Moreover, a mechanism concerning the electrochemical processes is proposed. 


\section{Materials and Methods}

\subsection{Synthesis and Characterization of Dihydro-benzoxazine Dimer Derivatives}

Benzoxazine dimers were synthesized by two steps, namely (a) Mannich reaction for preparing the benzoxazine monomers and (b) ring-opening reaction of the benzoxazine monomers and phenols. For the Mannich reaction, primary amines $(150 \mathrm{mmol})$, paraformaldehyde (300 mmol), and para-substituted (or ortho- and para-substituted) phenols $(150 \mathrm{mmol}$ ) were dissolved in dioxane (RCI Labscan, $100 \mathrm{~mL}$ ) and then refluxed for $6 \mathrm{~h}[29,48-50]$. After the reaction was complete, dark yellow solutions were obtained. The solvent was then removed under reduced pressure with a rotary evaporator. To remove unreacted starting materials and impurities, the solutions were extracted with $3 \mathrm{~N} \mathrm{NaOH}$ and deionized water. Note that dichloromethane was added prior to the liquid-liquid extraction. The extracted products were dried with anhydrous sodium sulfate (Ajax Finechem). Then, the dichloromethane solvent was removed with a rotary evaporator. As a result, viscous brown liquids containing benzoxazine monomers were obtained. Equimolar amounts of the benzoxazine monomers and phenols were then mixed without solvent. The mixture was stirred at $60^{\circ} \mathrm{C}$ for a day until the mixtures were solidified. Diethyl ether was added to the solidified mixtures to remove impurities, and the dihydro-benzoxazine dimers were collected as white precipitates. The chemical structures of dihydro-benzoxazine dimers synthesized and studied in this work are schematically shown in Figure 1.<smiles>[R2]c1cc([R])c(O)c(CN([R3])Cc2cc([R2])cc([R])c2O)c1</smiles>

(1) $R_{1}=H, R_{2}=M e, R_{3}=M e$

(2) $R_{1}=H, R_{2}=E t, R_{3}=M e$

(3) $\mathrm{R}_{1}=\mathrm{H}, \mathrm{R}_{2}=\mathrm{OMe}, \mathrm{R}_{3}=\mathrm{Me}$

(4) $R_{1}=M e, R_{2}=M e, R_{3}=M e$

(5) $R_{1}=H, R_{2}=M e, R_{3}=C y-H e x$

(6) $R_{1}=H, R_{2}=E t, R_{3}=C y-H e x$

(7) $\mathrm{R}_{1}=\mathrm{H}, \mathrm{R}_{2}=\mathrm{OMe}, \mathrm{R}_{3}=\mathrm{Cy}-\mathrm{Hex}$

(8) $R_{1}=\mathrm{Me}, \mathrm{R}_{2}=\mathrm{Me}, \mathrm{R}_{3}=\mathrm{Cy}-\mathrm{Hex}$

Figure 1. Chemical structure of the dihydro-benzoxazine dimers studied in this work.

To determine the chemical structures of the dihydro-benzoxazine dimers, Fouriertransform infrared spectroscopy (FTIR, Perkin Elmer FT-IR spectrometer, Spectrum 100 model, ATR mode) and nuclear magnetic resonance spectroscopy (NMR, Bruker AVANCE III NMR spectrometer, $500 \mathrm{MHz}$ for ${ }^{1} \mathrm{H}$ and $126 \mathrm{MHz}$ for ${ }^{13} \mathrm{C}$ ) were used. The dihydrobenzoxazine dimers were dissolved in $\mathrm{CDCl}_{3}$ prior to the NMR investigation.

To examine the crystalline phase purity of the obtained products, powder $\mathrm{X}$-ray diffraction (PXRD) was carried out at Beamline 1.1W, Synchrotron Light Research Institute, Thailand. For sample preparations, the crystal samples were ground into fine powders and then packed into a Kapton capillary with a diameter of $1.0 \mathrm{~mm}$. The capillary sample was attached onto a goniometer head, and the sample position was then adjusted. The goniometer-mounted capillary sample was attached to the sample stage, which continuously spun during the measurement. The synchrotron PXRD was carried out at room temperature in Debye-Scherrer geometry using monochromatic $\mathrm{X}$-ray radiation with the energy of $12 \mathrm{keV}$ (wavelength of $1.0332 \AA$ ). The one-dimensional Strip detector (Mythen6K 450, DECTRIS ${ }^{\circledR}$ ) was used for data collection.

Characterization details:

(1): FTIR $\left(\mathrm{cm}^{-1}\right): 3263(b r, \mathrm{O}-\mathrm{H}), 1498\left(v s, \mathrm{C}_{\mathrm{a}}-\mathrm{C}_{\mathrm{a}}\right), 1456\left(\mathrm{~m}, \mathrm{~N}-\mathrm{CH}_{3}\right), 1248(m, \mathrm{C}-\mathrm{O}), 1206(\mathrm{~m}$, C-N-C), $812(m, \mathrm{C}-\mathrm{N}-\mathrm{C}) ;{ }^{1} \mathrm{H}$ NMR $\left(\delta_{\mathrm{H}}, \mathrm{ppm}\right): 2.35(\mathrm{~s}, 9 \mathrm{H}), 3.80(\mathrm{~s}, 4 \mathrm{H}), 6.82(d, J=8.0 \mathrm{~Hz}$, $2 \mathrm{H}), 6.98(d, J=2.0 \mathrm{~Hz}, 2 \mathrm{H}), 7.01(d d, J=2.0,8.5 \mathrm{~Hz}, 2 \mathrm{H}) ;{ }^{13} \mathrm{C}$ NMR $\left(\delta_{C}, \mathrm{ppm}\right): 20.46$ $\left(-\mathrm{CH}_{3}\right), 40.85\left(\mathrm{CH}_{3}-\mathrm{NR}_{2}\right), 59.27\left(-\mathrm{CH}_{2}-\mathrm{NR}_{2}\right), 115.73\left(\mathrm{C}_{\mathrm{a}}\right), 122.50\left(\mathrm{C}_{\mathrm{a}}\right), 128.45\left(\mathrm{C}_{\mathrm{a}}\right), 129.38$ $\left(\mathrm{C}_{\mathrm{a}}\right), 130.65\left(\mathrm{C}_{\mathrm{a}}\right), 154.08\left(\mathrm{C}_{\mathrm{a}}\right), 154.10(\mathrm{C}-\mathrm{OH})$. (Yield: 88\%)

(2): FTIR $\left(\mathrm{cm}^{-1}\right): 3263(b r, \mathrm{O}-\mathrm{H}), 1497\left(v s, \mathrm{C}_{\mathrm{a}}-\mathrm{C}_{\mathrm{a}}\right), 1454\left(m, \mathrm{~N}-\mathrm{CH}_{3}\right), 1272(m, \mathrm{C}-\mathrm{O}), 1204(m$, $\mathrm{C}-\mathrm{N}-\mathrm{C}), 820(m, \mathrm{C}-\mathrm{N}-\mathrm{C}) ;{ }^{1} \mathrm{H}$ NMR $\left(\delta_{\mathrm{H}}, \mathrm{ppm}\right): 1.29(d, J=8.0 \mathrm{~Hz}, 6 \mathrm{H}), 2.36(s, 3 \mathrm{H}), 2.64(d$, 
$J=7.5 \mathrm{~Hz}, 4 \mathrm{H}), 3.81(s, 4 \mathrm{H}), 6.85(d, J=8.0 \mathrm{~Hz}, 2 \mathrm{H}), 6.99(d, J=2.2 \mathrm{~Hz}, 2 \mathrm{H}), 7.05(d d, J=2.0$, $8.0 \mathrm{~Hz}, 2 \mathrm{H}) ;{ }^{13} \mathrm{C} \mathrm{NMR}\left(\delta_{\mathrm{C}}, \mathrm{ppm}\right): 15.89\left(-\mathrm{CH}_{3}\right), 27.94\left(-\mathrm{CH}_{2}-\mathrm{C}_{\mathrm{a}}\right), 40.98\left(\mathrm{CH}_{3}-\mathrm{NR}_{2}\right), 59.24$ $\left(-\mathrm{CH}_{2}-\mathrm{N} R_{2}\right), 115.80\left(\mathrm{C}_{\mathrm{a}}\right), 122.31\left(\mathrm{C}_{\mathrm{a}}\right), 128.22\left(\mathrm{C}_{\mathrm{a}}\right), 129.47\left(\mathrm{C}_{\mathrm{a}}\right), 135.16\left(\mathrm{C}_{\mathrm{a}}\right), 154.19(\mathrm{C}-\mathrm{OH})$. (Yield: $89 \%$ )

(3): FTIR $\left(\mathrm{cm}^{-1}\right)$ : $3312(b r, \mathrm{O}-\mathrm{H}), 1493\left(v s, \mathrm{C}_{\mathrm{a}}-\mathrm{C}_{\mathrm{a}}\right), 1432\left(\mathrm{~m}, \mathrm{~N}-\mathrm{CH}_{3}\right), 1247(m, \mathrm{C}-\mathrm{O}), 1204$ $(m, \mathrm{C}-\mathrm{N}-\mathrm{C}), 1038(m, \mathrm{C}-\mathrm{O}), 813(\mathrm{~m}, \mathrm{C}-\mathrm{N}-\mathrm{C}) ;{ }^{1} \mathrm{H}$ NMR $\left(\delta_{\mathrm{H}}, \mathrm{ppm}\right): 2.36(\mathrm{~s}, 3 \mathrm{H}), 3.80(\mathrm{~s}, 4 \mathrm{H})$, $3.84(s, 6 \mathrm{H}), 6.76(d, J=3.0 \mathrm{~Hz}, 2 \mathrm{H}), 6.77-6.81(m, 2 \mathrm{H}), 6.85(d, J=8.5 \mathrm{~Hz}, 2 \mathrm{H}) ;{ }^{13} \mathrm{C}$ NMR $\left(\delta_{\mathrm{C}}\right.$, ppm): $40.98\left(\mathrm{CH}_{3}-\mathrm{N} R_{2}\right), 55.78\left(-\mathrm{CH}_{2}-\mathrm{NR}_{2}\right), 59.23\left(-\mathrm{CH}_{3}\right), 113.74\left(\mathrm{C}_{\mathrm{a}}\right), 116.03\left(\mathrm{C}_{\mathrm{a}}\right), 116.44$ $\left(\mathrm{C}_{\mathrm{a}}\right), 123.36\left(\mathrm{C}_{\mathrm{a}}\right), 150.12(\mathrm{C}-\mathrm{OH}), 152.76\left(\mathrm{C}-\mathrm{O}-\mathrm{CH}_{3}\right)$. (Yield: 83\%)

(4): FTIR (cm $\left.{ }^{-1}\right)$ : $3391(b r, \mathrm{O}-\mathrm{H}), 1482\left(v s, \mathrm{C}_{\mathrm{a}}-\mathrm{C}_{\mathrm{a}}\right), 1456\left(\mathrm{~m}, \mathrm{~N}-\mathrm{CH}_{3}\right), 1241(\mathrm{~m}, \mathrm{C}-\mathrm{O}), 1199$ $(m, \mathrm{C}-\mathrm{N}-\mathrm{C}), 846(m, \mathrm{C}-\mathrm{N}-\mathrm{C}) ;{ }^{1} \mathrm{H}$ NMR $\left(\delta_{\mathrm{H}}, \mathrm{ppm}\right): 2.32(\mathrm{~s}, 12 \mathrm{H}), 2.34(\mathrm{~s}, 3 \mathrm{H}), 3.77(\mathrm{~s}, 4 \mathrm{H})$, $6.83(d, J=2.5 \mathrm{~Hz}, 2 \mathrm{H}), 6.98(d, J=2.5 \mathrm{~Hz}, 2 \mathrm{H}) ;{ }^{13} \mathrm{C} \mathrm{NMR}\left(\delta_{\mathrm{C}}, \mathrm{ppm}\right): 15.86\left(-\mathrm{CH}_{3}\right), 20.42$ $\left(-\mathrm{CH}_{3}\right), 41.06\left(\mathrm{CH}_{3}-\mathrm{NR}_{2}\right), 59.35\left(-\mathrm{CH}_{2}-\mathrm{NR}_{2}\right), 121.41\left(\mathrm{C}_{\mathrm{a}}\right), 124.54\left(\mathrm{C}_{\mathrm{a}}\right), 128.40\left(\mathrm{C}_{\mathrm{a}}\right), 128.59$ $\left(\mathrm{C}_{\mathrm{a}}\right), 131.15\left(\mathrm{C}_{\mathrm{a}}\right), 151.95(\mathrm{C}-\mathrm{OH})$. (Yield: 80\%)

(5): FTIR ( $\left.\mathrm{cm}^{-1}\right)$ : 3217 (br, O-H), 1500 (vs, $\left.\mathrm{C}_{\mathrm{a}}-\mathrm{C}_{\mathrm{a}}\right), 1447$ ( $\left.m, \mathrm{~N}-\mathrm{C}_{\mathrm{cy}}\right), 1275$ ( $\left.m, \mathrm{C}-\mathrm{O}\right), 1209$ ( $m, \mathrm{C}-\mathrm{N}-\mathrm{C}), 819(m, \mathrm{C}-\mathrm{N}-\mathrm{C}) ;{ }^{1} \mathrm{H}$ NMR $\left(\delta_{\mathrm{H}}, \mathrm{ppm}\right): 1.16-1.24(m, 1 \mathrm{H}), 1.24-1.35(m, 2 \mathrm{H})$, 1.52-1.65 (m, 2H), 1.68-1.76 (m, 1H), 1.85-1.97 $(m, 2 \mathrm{H}), 2.03-2.14(m, 2 \mathrm{H}), 2.32(\mathrm{~s}, 6 \mathrm{H})$, 2.75-2.86 $(m, 1 \mathrm{H}), 3.85(s, 4 \mathrm{H}), 6.77(d, J=8.0 \mathrm{~Hz}, 2 \mathrm{H}), 6.93(d, J=2.5 \mathrm{~Hz}, 2 \mathrm{H}), 6.98(d d$, $J=2.5,8.0 \mathrm{~Hz}, 2 \mathrm{H}) ;{ }^{13} \mathrm{C}$ NMR $\left(\delta_{\mathrm{C}}, \mathrm{ppm}\right): 20.45\left(\mathrm{C}_{\mathrm{cy}}\right), 25.88\left(-\mathrm{CH}_{3}\right), 26.18\left(\mathrm{C}_{\mathrm{cy}}\right), 27.36\left(\mathrm{C}_{\mathrm{cy}}\right)$, $51.06\left(-\mathrm{CH}_{2}-\mathrm{N} R_{2}\right), 58.35\left(\mathrm{C}_{\mathrm{cy}}-\mathrm{N} R_{2}\right), 115.87\left(\mathrm{C}_{\mathrm{a}}\right), 122.32\left(\mathrm{C}_{\mathrm{a}}\right), 128.45\left(\mathrm{C}_{\mathrm{a}}\right), 129.31\left(\mathrm{C}_{\mathrm{a}}\right), 130.80$ $\left(\mathrm{C}_{\mathrm{a}}\right), 154.14(\mathrm{C}-\mathrm{OH})$. (Yield: $81 \%$ )

(6): FTIR ( $\left.\mathrm{cm}^{-1}\right)$ : $3232(b r, \mathrm{O}-\mathrm{H}), 1498\left(v s, \mathrm{C}_{\mathrm{a}}-\mathrm{C}_{\mathrm{a}}\right), 1447\left(m, \mathrm{~N}-\mathrm{C}_{\mathrm{cy}}\right), 1249(m, \mathrm{C}-\mathrm{O}), 1206(m$, C-N-C), $817(m, \mathrm{C}-\mathrm{N}-\mathrm{C}) ;{ }^{1} \mathrm{H}$ NMR $\left(\delta_{\mathrm{H}}, \mathrm{ppm}\right): 1.17-1.25(m, 2 \mathrm{H}), 1.27(t, J=7.5 \mathrm{~Hz}, 6 \mathrm{H})$, 1.29-1.33 $(m, 1 \mathrm{H}), 1.52-1.63(m, 2 \mathrm{H}), 1.69-1.77(m, 1 \mathrm{H}), 1.86-1.97(m, 2 \mathrm{H}), 2.08(d d, J=3.5$, $12.0 \mathrm{~Hz}, 2 \mathrm{H}), 2.62(q, J=7.5 \mathrm{~Hz}, 4 \mathrm{H}), 2.83(t t, J=3.5,12.5 \mathrm{~Hz}, 1 \mathrm{H}), 3.88(s, 4 \mathrm{H}), 6.82(d$, $J=8.0 \mathrm{~Hz}, 2 \mathrm{H}), 6.95(d, J=2.5 \mathrm{~Hz}, 2 \mathrm{H}), 7.02(d d, J=2.0,8.0 \mathrm{~Hz}, 2 \mathrm{H}) ;{ }^{13} \mathrm{C} \mathrm{NMR}\left(\delta_{\mathrm{C}}, \mathrm{ppm}\right)$ : $15.88\left(-\mathrm{CH}_{3}\right), 25.85\left(\mathrm{C}_{\mathrm{cy}}\right), 26.15\left(\mathrm{C}_{\mathrm{cy}}\right), 27.37\left(\mathrm{C}_{\mathrm{cy}}\right), 27.94\left(-\mathrm{CH}_{2}-\mathrm{C}_{\mathrm{a}}\right), 51.24\left(-\mathrm{CH}_{2}-\mathrm{NR}_{2}\right), 58.32$ $\left(\mathrm{C}_{\mathrm{cy}}-\mathrm{N} R_{2}\right), 116.00\left(\mathrm{C}_{\mathrm{a}}\right), 122.10\left(\mathrm{C}_{\mathrm{a}}\right), 128.21\left(\mathrm{C}_{\mathrm{a}}\right), 129.61\left(\mathrm{C}_{\mathrm{a}}\right), 135.19\left(\mathrm{C}_{\mathrm{a}}\right), 154.25(\mathrm{C}-\mathrm{OH})$. (Yield: $80 \%$ )

(7): FTIR ( $\left.\mathrm{cm}^{-1}\right)$ : $3269(b r, \mathrm{O}-\mathrm{H}), 1503\left(v s, \mathrm{C}_{\mathrm{a}}-\mathrm{C}_{\mathrm{a}}\right), 1430\left(m, \mathrm{~N}-\mathrm{C}_{\mathrm{cy}}\right), 1261(m, \mathrm{C}-\mathrm{O}), 1200(m$, C-N-C), $1041(m, \mathrm{C}-\mathrm{O}), 858(m, \mathrm{C}-\mathrm{N}-\mathrm{C}) ;{ }^{1} \mathrm{H}$ NMR $\left(\delta_{\mathrm{H}}, \mathrm{ppm}\right): 1.15-1.23(m, 1 \mathrm{H}), 1.27-1.36$ $(m, 2 \mathrm{H}), 1.53-1.63(m, 2 \mathrm{H}), 1.74(d, J=12.5 \mathrm{~Hz}, 1 \mathrm{H}), 1.93(d, J=12.5 \mathrm{~Hz}, 2 \mathrm{H}), 2.07(d, J=12.0$ $\mathrm{Hz}, 2 \mathrm{H}), 2.84-2.92(m, 1 \mathrm{H}), 3.83(\mathrm{~s}, 6 \mathrm{H}), 3.91(\mathrm{~s}, 4 \mathrm{H}), 6.72(d, J=3.0 \mathrm{~Hz}, 2 \mathrm{H}), 6.80(d d, J=3.5$, $9.0 \mathrm{~Hz}, 2 \mathrm{H}), 6.90(d, J=9.0 \mathrm{~Hz}, 2 \mathrm{H}) ;{ }^{13} \mathrm{C} \mathrm{NMR}\left(\delta_{\mathrm{C}}, \mathrm{ppm}\right): 25.68\left(\mathrm{C}_{\mathrm{cy}}\right), 25.92\left(\mathrm{C}_{\mathrm{cy}}\right), 27.36$ $\left(\mathrm{C}_{\mathrm{cy}}\right), 51.63\left(-\mathrm{CH}_{2}-\mathrm{N} R_{2}\right), 55.76\left(-\mathrm{CH}_{3}\right), 58.93\left(\mathrm{C}_{\mathrm{cy}}-\mathrm{N} R_{2}\right), 114.16\left(\mathrm{C}_{\mathrm{a}}\right), 116.13\left(\mathrm{C}_{\mathrm{a}}\right), 116.98$ $\left(\mathrm{C}_{\mathrm{a}}\right), 122.11\left(\mathrm{C}_{\mathrm{a}}\right), 149.90(\mathrm{C}-\mathrm{OH}), 152.95\left(\mathrm{C}-\mathrm{O}-\mathrm{CH}_{3}\right)$. (Yield: 80\%)

(8): FTIR ( $\left.\mathrm{cm}^{-1}\right)$ : $3452(b r, \mathrm{O}-\mathrm{H}), 1484\left(v s, \mathrm{C}_{\mathrm{a}}-\mathrm{C}_{\mathrm{a}}\right), 1451\left(m, \mathrm{~N}-\mathrm{C}_{\mathrm{cy}}\right), 1171(m, \mathrm{C}-\mathrm{O}), 1153$ $(m, \mathrm{C}-\mathrm{N}-\mathrm{C}), 854(m, \mathrm{C}-\mathrm{N}-\mathrm{C}) ;{ }^{1} \mathrm{H}$ NMR $\left(\delta_{\mathrm{H}}, \mathrm{ppm}\right): 1.14-1.23(m, 1 \mathrm{H}), 1.24-1.34(m, 2 \mathrm{H})$, $1.46-1.61(m, 2 \mathrm{H}), 1.73(d t, J=3.5,13.0 \mathrm{~Hz}, 1 \mathrm{H}), 1.91(d t, J=3.5,13.0 \mathrm{~Hz}, 2 \mathrm{H}), 2.03(d d, J=3.5$, $9.0 \mathrm{~Hz}, 2 \mathrm{H}), 2.30(d, J=4.5 \mathrm{~Hz}, 12 \mathrm{H}), 2.81(t t, J=3.5,12.0 \mathrm{~Hz}, 1 \mathrm{H}), 3.83(s, 4 \mathrm{H}), 6.79(d$, $J=2.0 \mathrm{~Hz}, 2 \mathrm{H}), 6.95(d, J=2.0 \mathrm{~Hz}, 2 \mathrm{H}) ;{ }^{13} \mathrm{C} \mathrm{NMR}\left(\delta_{\mathrm{C}}, \mathrm{ppm}\right): 15.90\left(-\mathrm{CH}_{3}\right), 20.45\left(\mathrm{C}_{\mathrm{cy}}\right), 25.78$ $\left(-\mathrm{CH}_{3}\right), 26.15\left(\mathrm{C}_{\mathrm{cy}}\right), 27.45\left(\mathrm{C}_{\mathrm{cy}}\right), 51.48\left(-\mathrm{CH}_{2}-\mathrm{NR}_{2}\right), 57.43\left(\mathrm{C}_{\mathrm{cy}}-\mathrm{NR}_{2}\right), 121.69\left(\mathrm{C}_{\mathrm{a}}\right), 124.83$ $\left(C_{a}\right), 128.45\left(C_{a}\right), 128.50\left(C_{a}\right), 130.90\left(C_{a}\right), 152.06$. (Yield: 89\%)

Note for abbreviation used herein: $\mathrm{cy}=$ cyclohexyl and $\mathrm{a}=$ aromatic.

\subsection{Single-Crystal X-ray Diffraction (SC-XRD)}

Since the crystal structures of the dihydro-benzoxazine dimers discussed in this work have been previously reported (see Results and Discussion Session) except that of compound (7), only the single crystal of (7) was measured to examine its crystallographic information. Colorless crystals of (7) were crystallized after dissolving the white precipitate of (7) in hot propan-2-ol and then left to cool down naturally for 3 days. A single crystal 
of (7) was selected under an optical microscope and mounted on a crystal holder. The diffraction spots were recorded on a Bruker D8 Venture diffractometer using Cu K $\alpha$ radiation $(\lambda=1.54178 \AA)$ at room temperature $(298 \mathrm{~K})$. Cell refinement and data reduction were performed using SAINT [51], while absorption correction was carried out by the multi-scan method using SADABS [52]. Using Olex2 [53], the structure was solved by the ShelXT [54] structure solution program with the intrinsic phasing method, and it was then refined using the ShelXL [55] refinement package by a least-squares minimization. All non-hydrogen atoms were treated anisotropically. The $\mathrm{C}$-bound $\mathrm{H}$ atoms were placed in idealized positions ( $\mathrm{C}-\mathrm{H}=0.93-0.98 \AA$ depending on their hybridization) and refined as riding atoms. The constraint $U_{\text {iso }}(\mathrm{H})=1.2 U_{\text {eq }}$ (carrier) or $1.5 U_{\text {eq }}$ (methyl $\mathrm{C}$ ) was applied in all cases. However, the $\mathrm{O}$-bound $\mathrm{H}$ atoms that were responsible for the $\mathrm{H}$-bond formation were located in a different Fourier map and refined freely. The molecular graphics and materials for publication were prepared using the Mercury software package [56]. The corresponding crystal data and refinement details of (7) are listed in Table 1.

Table 1. Crystallographic data and structure refinement details for the compound (7).

\begin{tabular}{|c|c|}
\hline $\begin{array}{l}\text { Crystallographic Data } \\
\text { and Structural Refinement Details }\end{array}$ & Dihydro-benzoxazine Dimer (7) \\
\hline CCDC number & 2092708 \\
\hline Empirical formula & $\mathrm{C}_{22} \mathrm{H}_{29} \mathrm{NO}_{4}$ \\
\hline Formula weight & 371.46 \\
\hline Temperature/K & 298 \\
\hline Crystal system & Monoclinic \\
\hline Space group & $\mathrm{P} 22_{1} / \mathrm{n}$ \\
\hline $\mathrm{a} / \AA$ & $11.4973(2)$ \\
\hline $\mathrm{b} / \AA$ & $10.5236(2)$ \\
\hline $\mathrm{c} / \AA$ & $17.6607(4)$ \\
\hline$\alpha /^{\circ}$ & 90 \\
\hline$\beta /{ }^{\circ}$ & $108.6290(10)$ \\
\hline$\gamma /{ }^{\circ}$ & 90 \\
\hline Volume $/ \AA^{3}$ & 2024.87(7) \\
\hline $\mathrm{Z}$ & 4 \\
\hline$\varrho_{\text {calc }} \mathrm{g} / \mathrm{cm}^{3}$ & 1.218 \\
\hline$\mu / \mathrm{mm}^{-1}$ & 0.669 \\
\hline $\mathrm{F}(000)$ & 800.0 \\
\hline Crystal size $/ \mathrm{mm}^{3}$ & $0.05 \times 0.05 \times 0.05$ \\
\hline Radiation & $\mathrm{CuK} \alpha(\lambda=1.54178)$ \\
\hline $2 \Theta$ range for data collection $/{ }^{\circ}$ & 9.928 to 140.094 \\
\hline Index ranges & $-12 \leq \mathrm{h} \leq 14,-12 \leq \mathrm{k} \leq 12,-21 \leq 1 \leq 20$ \\
\hline Reflections collected & 28878 \\
\hline Independent reflections & $3677\left[R_{\text {int }}=0.0271, R_{\text {sigma }}=0.0178\right]$ \\
\hline Data/restraints/parameters & $3677 / 0 / 254$ \\
\hline Goodness-of-fit on $\mathrm{F}^{2}$ & 1.103 \\
\hline Final $R$ indexes $[\mathrm{I}>=2 \sigma(\mathrm{I})]$ & $\mathrm{R}_{1}=0.0444, \mathrm{wR}_{2}=0.1295$ \\
\hline Final $\mathrm{R}$ indexes [all data] & $\mathrm{R}_{1}=0.0486, \mathrm{wR}_{2}=0.1333$ \\
\hline Largest diff. peak/hole/e $\AA^{-3}$ & $0.14 /-0.14$ \\
\hline
\end{tabular}

\subsection{Electrochemical Study}

The redox behavior of eight dihydro-benzoxazine dimers was investigated by cyclic voltammetry $(\mathrm{CV})$ in acetonitrile $(\mathrm{ACN})$. A CV experiment was performed using a PalmSens 4 potentiostat/galvanostat controlled by the PSTrace 5.8 software (PalmSens, Houten, The Netherlands). All cyclic voltammetric measurements were carried out with a threeelectrode setup consisted of a Pt-planar disk ( $3 \mathrm{~mm}$ diameter) as a working electrode, an $\mathrm{Ag} / \mathrm{Ag}^{+}\left(0.01 \mathrm{M} \mathrm{AgNO}_{3}\right)$ as a reference electrode, and a Pt plate as a counter electrode. All dihydro-benzoxazine dimers were dissolved in ACN to attain a concentration of $2 \mathrm{mM}$. In addition, $0.1 \mathrm{M}$ tetrabutylammonium hexafluorophosphate $\left(\mathrm{TBAPF}_{6}\right)$ was added as an 
electrolyte. Prior to CV measurements, the solution of dihydro-benzoxazine dimers in $\mathrm{ACN}$ was purged with argon gas for $10 \mathrm{~min}$ to remove oxygen.

\subsection{Computational Simulation}

Density Functional Theory (DFT) calculations were performed with the B3LYP density functional and the $6-311++G(d, p)$ basis set. Solvent interactions were taken into consideration by using the polarizable continuum model (PCM) for acetonitrile (ACN) [57]. Geometry optimizations were conducted by using the Berny algorithm. Special options used included the use of a finer integration grid and higher two-electron integral accuracy than used by default (integral = (ultrafine, acc $2 \mathrm{e}=12)$ ). The Gaussian 09 code was used in all calculations [58]. The highest occupied molecular orbital (HOMO) and the lowest unoccupied molecular orbital (LUMO) were visualized with the VESTA program.

\section{Results and Discussion}

\subsection{Crystal Structure, Crystal Packing, and Hirshfeld Surface Analysis of the Dihydro-benzoxazine Dimer Derivatives}

Crystals of eight dihydro-benzoxazine dimer derivatives possessing four different substituent groups on the phenol rings with two different groups at the $\mathrm{N}$-substituent position have been prepared. As mentioned previously, only the crystal structure of (7) has not been reported yet. Therefore, the analysis of crystallographic information of (7) is compared with the other derivatives reported in the literature [59-65]. Moreover, the correlation of crystal structures, crystal packing, and interactions within the crystals with respect to the chemical functionalities of these eight dihydro-benzoxazine dimer derivatives are explained.

The molecular structure of (7) based on the single-crystal X-ray crystallographic data is illustrated in Figure 2 to be representative of the other derivatives. To compare the crystal structures of the dihydro-benzoxazine dimers, a similar atomic labeling scheme as shown in Figure 2 is applied to the other derivatives. Specifically, the tertiary-amine nitrogen atom (N1) of the derivative (7) adopts a distorted trigonal pyramidal shape as seen from the $\mathrm{C}-\mathrm{N}-\mathrm{C}$ bond angles: $\mathrm{C} 8-\mathrm{N} 1-\mathrm{C} 9=110.77(12)^{\circ}, \mathrm{C} 8-\mathrm{N} 1-\mathrm{C} 17=112.80(12)^{\circ}$, and $\mathrm{C} 10-\mathrm{N} 1-\mathrm{C} 19=114.66(11)^{\circ}$. The sum of these three $\mathrm{C}-\mathrm{N}-\mathrm{C}$ bond angles of the derivative (7) is $338^{\circ}$, illustrating the deviation of the bond angles from the theoretical trigonal pyramidal geometry (showing the sum of the bond angles $=321^{\circ}$ ). This distorted trigonal pyramidal structural feature is observed in the other derivatives as well, since the sums of three $\mathrm{C}-\mathrm{N}-\mathrm{C}$ bond angles of all the dihydro-benzoxazine dimer derivatives are in the range from $333^{\circ}$ to $338^{\circ}$ (as seen from the $\mathrm{C}-\mathrm{N}-\mathrm{C}$ bonds listed in Table 2). Interestingly, the $\mathrm{N} 1-\mathrm{C} 17$ ( $\mathrm{N}-$ $\mathrm{CH}_{3}$ ) bond lengths of the dihydro-benzoxazine dimers (1)-(4) are shorter than the N1-C17 $\left(\mathrm{N}-\mathrm{C}_{\text {cyclohexyl }}\right)$ bond lengths of the dihydro-benzoxazine dimers (5)-(8). Consequently, the bond angles corresponding with the $\mathrm{N}$-substituent carbon atom of the cyclohexyl group (C17) in the compounds (5)-(8) are expanded more than those of the methyl group (C17) in the compounds (1)-(4). For instance, the C9-N1-C17 bond angles of the compounds (1)-(4) are ranged from $111^{\circ}$ to $112^{\circ}$, while the $\mathrm{C} 9-\mathrm{N} 1-\mathrm{C} 17$ bond angles of the compounds (5)-(8) are ranged from $114^{\circ}$ to $115^{\circ}$. Moreover, the $\mathrm{C} 8-\mathrm{N} 1-\mathrm{C} 17$ bond angles are also increased from $111^{\circ}$ in the compounds (1)-(4) to $113^{\circ}$ in the compounds (5)-(8). The elongation of the N1-C17 bond lengths, the expansion of the C8-N1-C17 and C9-N1-C17 bond angles, and the larger sums of the $\mathrm{C}-\mathrm{N}-\mathrm{C}$ bond angles are due to the greater steric effect of the $\mathrm{N}$-cyclohexyl substituent than that of the N-methyl substituent. In summary, the steric hindrance of the $\mathrm{N}$-substituent group in the dihydro-benzoxazine dimer derivatives plays a significant role in the degree of distortion of the trigonal pyramidal structure.

When closely considering the other structural parameters of the dihydro-benzoxazine dimer (7), the $\mathrm{C}-\mathrm{O}$ bond lengths range from 1.3686(19) to 1.415(2) $\AA$. The $\mathrm{C}-\mathrm{O}$ bonds of the $-\mathrm{OCH}_{3}$ groups are relatively longer than those of $\mathrm{C}_{\text {aromatic }}-\mathrm{O}$ bonds, as expected from their different hybridization. The non-hydrogen atoms of the first methylene(4-methoxyphenol) moiety $(\mathrm{C} 1-\mathrm{C} 8 / \mathrm{O} 1 / \mathrm{O} 3)$ are situated planarly, as illustrated by a very small r.m.s. deviation 
from the mean plane of $0.02 \AA$. However, the other methylene(4-methoxyphenol) moiety constructed from $\mathrm{C} 9-\mathrm{C} 16 / \mathrm{O} 2 / \mathrm{O} 4$ shows a slightly higher deviation from planarity, with the r.m.s. deviation from the mean plane of $0.07 \AA$. The calculated dihedral angle between the two mean planes of the methylene(4-methoxyphenol) moieties is $79.00(5)^{\circ}$. The cyclohexyl substituent adopts a regular chair conformation as seen from the $\mathrm{C}-\mathrm{C}-\mathrm{C}$ bond angles, which are in the range from $110.6(2)^{\circ}$ to $111.89(18)^{\circ}$. This arrangement of the cyclohexyl group is also found in the derivatives (5), (6), and (8).

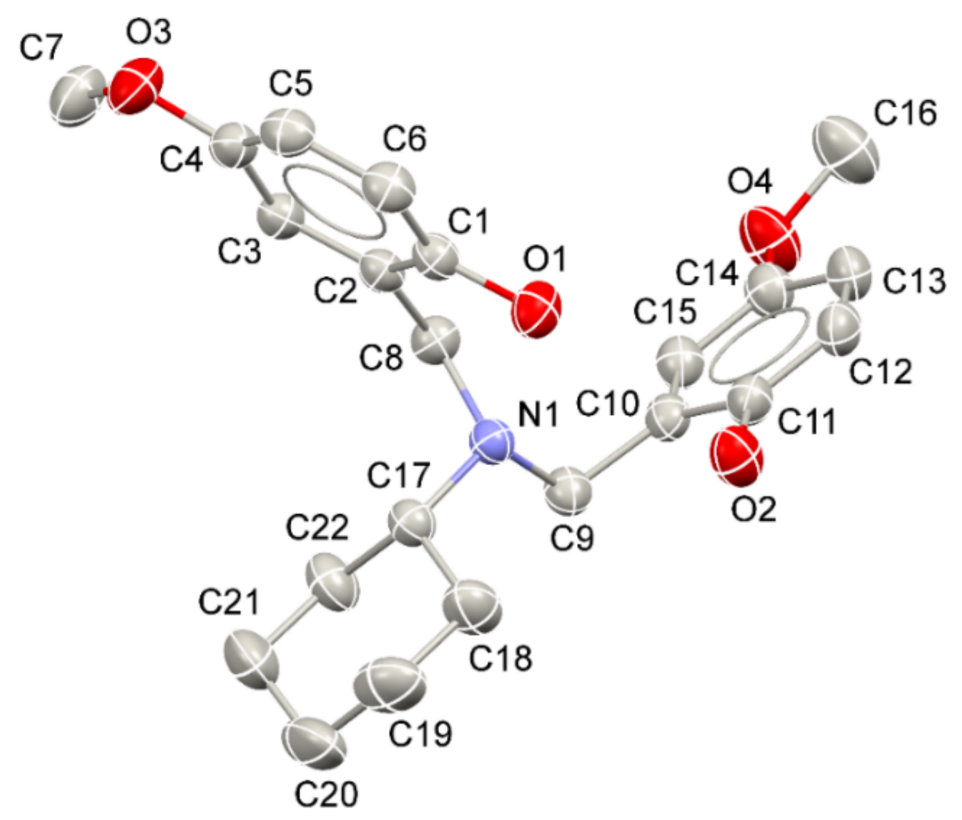

Figure 2. Molecular structure and non-IUPAC labeling scheme of the dihydro-benzoxazine dimer (7) with displacement ellipsoids drawn at the $30 \%$ probability level.

Table 2. Selected bond lengths and bond angles of all the eight dihydro-benzoxazine dimer derivatives.

\begin{tabular}{ccccccccc}
\hline Dihydro-benzoxazine Dimer & $\mathbf{( 1 )}$ & $\mathbf{( 2 )}$ & $\mathbf{( 3 )}$ & $\mathbf{( 4 )}$ & $\mathbf{( 5 )}$ & $\mathbf{( 6 )}$ & $\mathbf{( 7 )}$ & $\mathbf{( 8 )}$ \\
\hline Reference & {$[59]$} & {$[60]$} & {$[61]$} & {$[62]$} & {$[63]$} & {$[64]$} & This work & {$[65]$} \\
\hline CCDC number & 613813 & 1434969 & 889808 & 887033 & 643602 & 907527 & 2092708 & 2014264 \\
\hline Measurement temperature (K) & $283-303$ & $283-303$ & $283-303$ & $283-303$ & $283-303$ & $283-303$ & 298 & 100 \\
\hline Bond length (A) & & & & & & & & \\
\hline O1-H1 & $0.829(9)$ & $0.844(16)$ & $0.88(2)$ & $1.04(3)$ & $0.95 *$ & $0.94(3)$ & $0.93(3)$ & $0.89(4)$ \\
O2-H2 & $0.834(9)$ & $0.904(15)$ & $0.98(3)$ & $0.95(3)$ & $0.93 *$ & $0.88(3)$ & $0.90(3)$ & $0.99(4)$ \\
N1-C8 & $1.458(2)$ & $1.468(3)$ & $1.4714(17)$ & $1.472(2)$ & $1.477(2)$ & $1.474(2)$ & $1.4739(19)$ & $1.482(3)$ \\
N1-C9 & $1.4692(18)$ & $1.469(3)$ & $1.4726(17)$ & $1.473(2)$ & $1.482(2)$ & $1.4756(19)$ & $1.4777(19)$ & $1.479(2)$ \\
N1-C17 & $1.461(2)$ & $1.460(3)$ & $1.459(2)$ & $1.456(2)$ & $1.484(2)$ & $1.4833(19)$ & $1.4822(19)$ & $1.485(2)$ \\
\hline Bond angle $\left(^{\circ}\right)$ & & & & & & & & \\
\hline C8-N1-C9 & $111.85(11)$ & $112.4(2)$ & $111.83(11)$ & $110.75(12)$ & $110.5(1)$ & $111.05(12)$ & $110.77(12)$ & $109.97(15)$ \\
C8-N1-C17 & $111.19(13)$ & $111.2(2)$ & $111.38(12)$ & $111.00(14)$ & $112.9(1)$ & $112.92(12)$ & $112.80(12)$ & $112.59(15)$ \\
C9-N1-C17 & $111.69(12)$ & $112.2(2)$ & $110.81(12)$ & $111.41(14)$ & $114.8(1)$ & $114.48(11)$ & $114.66(11)$ & $115.09(15)$ \\
\hline Sum of the C-N-C angles & 335 & 336 & 334 & 333 & 338 & 338 & 338 \\
\hline
\end{tabular}

The values with the asterisk $\left(^{*}\right)$ contain no standard uncertainties since they are measured by Mercury software.

Considering the crystal packing of (7), the intramolecular hydrogen bonds and the intermolecular hydrogen bonding ring (as depicted in Figure 3) play an important role in the hydrogen-bonding framework of (7). Correspondingly, the refined bond distances and bond angles are tabulated in Table 2 . The freely refined positions of O-bound hydrogen 
atoms show that the $\mathrm{H} 1$ atom is located inside of the methylene-aza-methylene bridge, while the $\mathrm{H} 2$ atom is pointing outwards. The $\mathrm{O} 2-\mathrm{H} 2$ distance is $0.90(3) \AA$, while the O1-H1 bond length $(0.93(3) \AA)$. As observed in the crystal structure, the location of the $\mathrm{H} 1$ atom is suitable for the formation of the intramolecular $\mathrm{O} 1-\mathrm{H} 1 \cdots \mathrm{N} 1$ hydrogen bonds with $S(6)$ graph set [66-68], as shown in Figure 3a. Note that this intramolecular hydrogen bonding is remarkably stable due to the formation of a six-membered ring. Interestingly, such an intramolecular $\mathrm{O}-\mathrm{H} \cdots \mathrm{N}$ hydrogen bond is commonly observed in compounds containing the benzene ring with -OH and azamethylene substituents at ortho-positions of each other [69], especially the dihydro-benzoxazine dimer derivatives (see a comparison in Table 3) [59-65]. This observation highlights the resemble hydrogen-bonding interactions within the eight dihydro-benzoxazine dimer crystals regardless of the different substituent groups on the phenol rings and the $\mathrm{N}$-substituent position. Furthermore, it can be applied to the interactions of polybenzoxazines with other materials and, consequently, their resulting properties [70]. Although the $\mathrm{H} 1$ is situated inside the methylene-aza-methylene bridge, the intramolecular $\mathrm{O} 1-\mathrm{H} 1 \cdots \mathrm{O} 2$ hydrogen bonds with the $S(10)$ graph-set motifs are not likely to be formed since the $\mathrm{O} 1 \cdots \mathrm{O} 2$ distances are too large and the $\mathrm{O} 1-\mathrm{H} 1 \cdots \mathrm{O} 2$ angles are too small [60].

Apart from the intramolecular hydrogen bonds, the intermolecular hydrogen bonds $(\mathrm{O}-\mathrm{H} \cdots \mathrm{O})$ are also found when $\mathrm{O} 1$ behaves as a $\mathrm{H}$-bond acceptor. In the crystal packing of (7), two intermolecular $\mathrm{O}-\mathrm{H} \cdots \mathrm{O}$ hydrogen bonds $(\mathrm{O} 2-\mathrm{H} 2 \cdots \mathrm{O} 1)$ link two inversion-related molecules of the compound (7) together, giving rise to a dimeric structure with an $R_{2}{ }^{2}(20)$ motif as illustrated in Figure $3 b$. Interestingly, this $R_{2}^{2}(20)$ motif is also found in the other dihydro-benzoxazine dimers (compound (1)-(7)) [59-64]. Note that the $\mathrm{O} 2-\mathrm{H} 2 \cdots \mathrm{O} 1$ bond angle in the compound (4) is significantly lower than the other compounds ((1) to (7)). In detail, the $\mathrm{O} 2-\mathrm{H} 2 \cdots \mathrm{O} 1$ bond angle in the compound (4) is about $158^{\circ}$, while the $\mathrm{O} 2-\mathrm{H} 2 \cdots \mathrm{O} 1$ bond angles of the other compounds are ranged from $168^{\circ}$ to $176^{\circ}$, because compound (4) has both the ortho- and para- substituent groups with respect to the- $\mathrm{OH}$ groups in both the phenol rings, indicating the larger steric effect. The dihydro-benzoxazine dimer (8) does not form $R_{2}{ }^{2}(20)$; however, it forms a $C(10) \mathrm{H}$-bond chain instead, as it possesses higher numbers of substituents and with bulkier chemical groups (Table 3) [65]. It indicates herein that the different steric hindrance of both the $\mathrm{N}$-substituent and the phenol substituent groups of the dihydro-benzoxazine dimer derivatives shows the influence on the hydrogenbond interactions within the crystals. Note that the existence of $\mathrm{O}-\mathrm{H} \cdots \mathrm{O}$ interactions stabilizes the crystal packing of the compounds (1)-(8), making it readily crystallize at room temperature upon solvent evaporation.

(a)

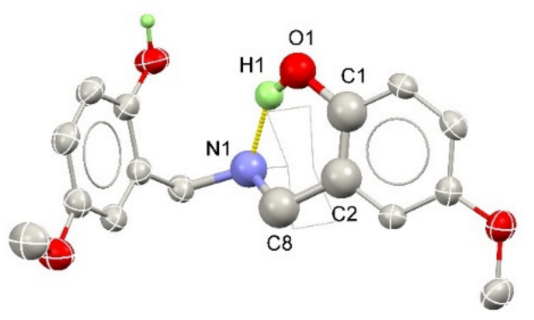

(b)

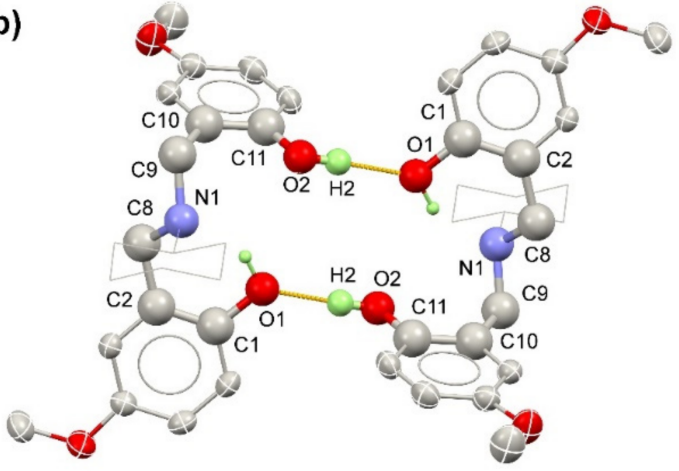

Figure 3. (a) The intramolecular $S(6) \mathrm{O}-\mathrm{H} \cdots \mathrm{N}$ hydrogen bonding and (b) the intermolecular $R_{2}{ }^{2}(20)$ $\mathrm{O}-\mathrm{H}$... O hydrogen bonding. The atoms regarding the $\mathrm{H}$-bond motifs are displayed in ball-and-stick style, while other atoms are drawn as displacement ellipsoids with $30 \%$ probability level. 
Table 3. Geometries of $\mathrm{O}-\mathrm{H} \cdots \mathrm{N}$ and $\mathrm{O}-\mathrm{H} \cdots \mathrm{O}$ hydrogen bonding interactions $\left(\AA{ }^{\circ}{ }^{\circ}\right)$.

\begin{tabular}{|c|c|c|c|c|c|c|c|}
\hline $\begin{array}{c}\text { Dihydro-benzoxazine } \\
\text { Dimer }\end{array}$ & Reference & $\mathbf{D}-\mathbf{H} \cdots \mathbf{A}$ & $\mathrm{d}(\mathrm{D}-\mathrm{H}) / \AA ̊$ & $\mathrm{~d}(\mathbf{H} \cdots \mathbf{A}) / \AA$ & $\mathrm{d}(\mathbf{D} \cdots \mathbf{A}) / \AA ̊$ & $\mathbf{D}-\mathbf{H} \cdots \mathbf{A} /^{\circ}$ & $\begin{array}{c}\text { Graph Set } \\
{[66-68]}\end{array}$ \\
\hline \multirow[t]{2}{*}{ (1) } & [59] & $\mathrm{O} 1-\mathrm{H} 1 \cdots \mathrm{N} 1$ & $0.829(9)$ & $1.898(13)$ & 2.6594(15) & $152(2)$ & $S(6)$ \\
\hline & & $\mathrm{O} 2-\mathrm{H} 2 \cdots \mathrm{O} 1$ & $0.834(9)$ & 1.881(10) & $2.7065(15)$ & $170(2)$ & $R_{2}^{2}(20)$ \\
\hline \multirow[t]{2}{*}{ (2) } & [60] & $\mathrm{O} 1-\mathrm{H} 1 \cdots \mathrm{N} 1$ & $1.00(5)$ & $1.79(4)$ & 2.642(3) & $141(4)$ & $S(6)$ \\
\hline & & $\mathrm{O} 2-\mathrm{H} 2 \cdots \mathrm{O} 1$ & $0.84(3)$ & $1.86(3)$ & $2.701(3)$ & 171(3) & $R_{2}^{2}(20)$ \\
\hline \multirow[t]{2}{*}{ (3) } & [61] & $\mathrm{O} 1-\mathrm{H} 1 \cdots \mathrm{N} 1$ & $0.98(3)$ & $1.78(3)$ & $2.6679(16)$ & $149(2)$ & $S(6)$ \\
\hline & & $\mathrm{O} 1-\mathrm{H} 1 \cdots \mathrm{O} 2$ & $0.88(3)$ & $1.89(3)$ & $2.7550(16)$ & $169(2)$ & $R_{2}{ }^{2}(20)$ \\
\hline \multirow[t]{2}{*}{ (4) } & [62] & $\mathrm{O} 1-\mathrm{H} 1 \cdots \mathrm{N} 1$ & $1.03(3)$ & $1.71(3)$ & $2.6895(18)$ & $156(2)$ & $S(6)$ \\
\hline & & $\mathrm{O} 2-\mathrm{H} 2 \cdots \mathrm{O} 1$ & $0.94(3)$ & 2.02(4) & $2.9114(18)$ & $158(2)$ & $R_{2}{ }^{2}(20)$ \\
\hline \multirow[t]{2}{*}{$(5)^{*}$} & [63] & $\mathrm{O} 1-\mathrm{H} 1 \cdots \mathrm{N} 1$ & 0.95 & 1.80 & 2.60 & 145 & $S(6)$ \\
\hline & & $\mathrm{O} 2-\mathrm{H} 2 \cdots \mathrm{O} 1$ & 0.93 & 1.77 & 2.70 & 176 & $R_{2}{ }^{2}(20)$ \\
\hline \multirow[t]{2}{*}{ (6) } & [64] & $\mathrm{O} 1-\mathrm{H} 1 \cdots \mathrm{N} 1$ & $0.94(3)$ & $1.79(3)$ & 2.6352(19) & 147.8(19) & $S(6)$ \\
\hline & & $\mathrm{O} 2-\mathrm{H} 2 \cdots \mathrm{O} 1$ & $0.88(3)$ & $1.84(3)$ & $2.708(2)$ & 168(3) & $R_{2}{ }^{2}(20)$ \\
\hline \multirow[t]{2}{*}{ (7) } & This work & $\mathrm{O} 1-\mathrm{H} 1 \cdots \mathrm{N} 1$ & $0.93(3)$ & $1.79(3)$ & $2.6436(17)$ & $151(2)$ & $S(6)$ \\
\hline & & $\mathrm{O} 2-\mathrm{H} 2 \cdots \mathrm{O} 1$ & $0.90(3)$ & $1.85(3)$ & $2.7464(19)$ & $176(2)$ & $R_{2}^{2}(20)$ \\
\hline \multirow[t]{2}{*}{ (8) } & [65] & $\mathrm{O} 1-\mathrm{H} 1 \cdots \mathrm{N} 1$ & $0.89(4)$ & $1.81(4)$ & $2.630(2)$ & $153(3)$ & $S(6)$ \\
\hline & & $\mathrm{O} 2-\mathrm{H} 2 \cdots \mathrm{O} 1$ & $0.99(4)$ & $1.87(4)$ & $2.741(2)$ & $145(3)$ & $C(10)$ \\
\hline
\end{tabular}

* The values of the compound (5) contain no standard uncertainties since they are measured by Mercury software.

The significant interactions within the crystal of (7) can be visually determined by analyzing Hirshfeld surfaces (HS) [71,72] using Crystal Explorer 17.5 software [73]. Views of the Hirshfeld surface for the compound (7) mapped over $d_{\text {norm }}$ in the range from -0.66 to +1.47 arbitrary units are illustrated in Figure 4 . The faint red spots around $\mathrm{O} 1$ and $\mathrm{H} 2$ confirm the intermolecular $\mathrm{O} 2-\mathrm{H} 2 \cdots \mathrm{O} 1$ hydrogen bonds, while the smaller red spot near $\mathrm{H} 6$ corresponds to the relatively weaker $\mathrm{C}-\mathrm{H} \cdots \mathrm{C}$ interactions (Figure 4). No red spots close to the $\mathrm{N} 1$ atom are found, implying that the $\mathrm{O}-\mathrm{H} \cdots \mathrm{N}$ interaction is not a major contributor in stabilizing the crystal packing of the compound (7). This observation is also recognized in the other dihydro-benzoxazine dimer derivatives, which indicates the common intermolecular interactions for the crystal packing of this class of compounds.

To obtain a quantitative contribution of each contact on the crystal packing, the corresponding 2D fingerprint plots are calculated [74]. The full fingerprint plot and those delineated into $\mathrm{H} \cdots \mathrm{H}, \mathrm{H} \cdots \mathrm{O} / \mathrm{O} \cdots \mathrm{H}$, and $\mathrm{H} \cdots \mathrm{C} / \mathrm{C} \cdots \mathrm{H}$ interactions are illustrated in Figure 4. The fingerprint plots reveal that the significant interactions and their contributions in the crystal structure of the compound (7) are $\mathrm{H} \cdots \mathrm{H}(67.1 \%), \mathrm{H} \cdots \mathrm{O} / \mathrm{O} \cdots \mathrm{H}(15.4 \%)$, and $\mathrm{H} \cdots \mathrm{C} / \mathrm{C} \cdots \mathrm{H}(14.3 \%)$, of which the contributions add up to $96.8 \%$. The two most important contacts, namely $\mathrm{H} \cdots \mathrm{H}$ contacts and $\mathrm{H} \cdots \mathrm{O} / \mathrm{O} \cdots \mathrm{H}$ contacts (with a joint contribution of $82.5 \%$ ), are characterized by a single spike at $d_{\mathrm{e}}+d_{\mathrm{i}} \simeq 2.0 \AA$ and a pair of peaks at $d_{\mathrm{e}}+d_{\mathrm{i}} \simeq$ $1.75 \AA$, respectively. These results suggest that the molecular packing within the crystal of (7) is majorly held by hydrogen bonds. In addition to the hydrogen bonds, the molecules also interact through the $\mathrm{C}-\mathrm{H} \cdots \mathrm{C}$ and/or $\mathrm{C}-\mathrm{H} \cdots \pi$ interactions, as seen from the presence of a pair of peaks of $\mathrm{H} \cdots \mathrm{C} / \mathrm{C} \cdots \mathrm{H}$ contact at $d_{\mathrm{e}}+d_{\mathrm{i}} \simeq 2.75 \AA$. For other dihydro-benzoxazine dimer derivatives, the contributions of each contact are listed in Table 4. It is noteworthy that the $\mathrm{H} \cdots \mathrm{H}$ contact is the most significant contact in the crystals of all the derivatives studied in this work. However, the percentage contribution of the $\mathrm{H} \cdots \mathrm{H}$ contact is lowered in the case of the compounds (3) and (7), compared to the other derivatives. Moreover, the contribution of the $\mathrm{H} \cdots \mathrm{O} / \mathrm{O} \cdots \mathrm{H}$ contacts of the derivatives (3) and (7) are higher than the other derivatives due to the presence of the $-\mathrm{OCH}_{3}$ substituent groups. 

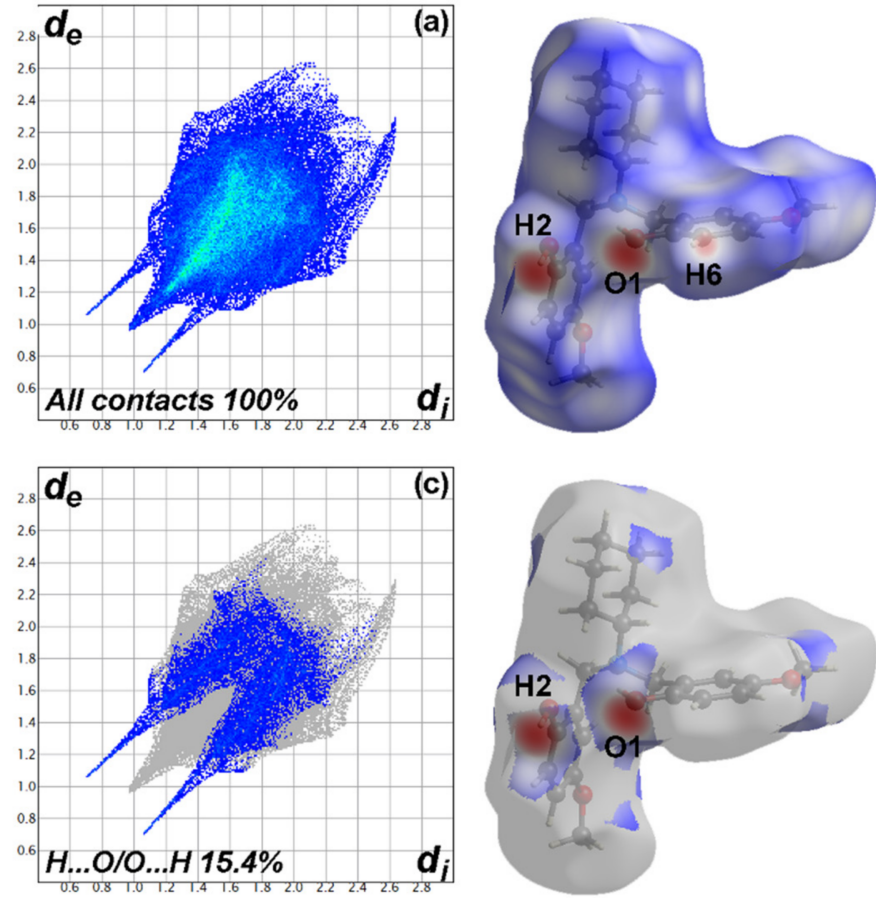
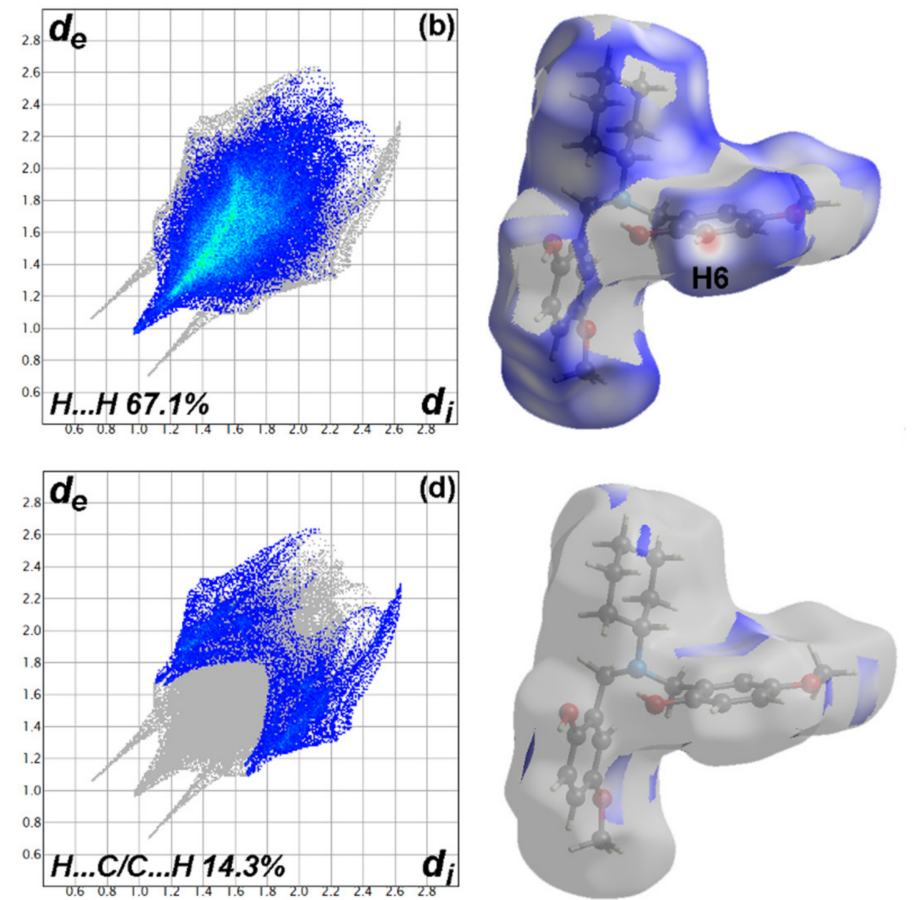

Figure 4. The two-dimensional fingerprint plots showing (a) all interactions and those delineated into (b) $\mathrm{H} \cdots \mathrm{H}$, (c) $\mathrm{H} \cdots \mathrm{O} / \mathrm{O} \cdots \mathrm{H}$, and (d) $\mathrm{H} \cdots \mathrm{C} / \mathrm{C} \cdots \mathrm{H}$ interactions, together with their corresponding views of the Hirshfeld surface for the compound (7). Note that Hirshfeld surface is mapped over $d_{\text {norm }}$ in the range from -0.66 to +1.47 arbitrary units and the $d_{\mathrm{i}}$ and $d_{\mathrm{e}}$ values are the closest internal and external distances (in $\AA$ ) from given points on the Hirshfeld surface.

Table 4. Contributions of the contacts found in the crystals of most of the eight dihydro-benzoxazine dimers derivatives calculated from the 2D fingerprint plots of the Hirshfeld surfaces.

\begin{tabular}{|c|c|c|c|c|c|c|c|c|}
\hline Dihydro-benzoxazine Dimer & (1) & (2) & (3) & (4) & $(5) *$ & (6) & (7) & (8) \\
\hline Reference & [59] & {$[60]$} & [61] & [62] & [63] & [64] & This work & [65] \\
\hline CCDC number & 613813 & 1434969 & 889808 & 887033 & 643602 & 907527 & 2092708 & 2014264 \\
\hline Measurement temperature (K) & $283-303$ & $283-303$ & $283-303$ & $283-303$ & $283-303$ & $283-303$ & 298 & 100 \\
\hline The $d_{\text {norm }}$ range for HS (a.u.) & $\begin{array}{l}-0.68 \text { to } \\
+1.56\end{array}$ & $\begin{array}{c}-0.68 \\
\text { to }+1.36\end{array}$ & $\begin{array}{l}-0.64 \text { to } \\
+1.36\end{array}$ & $\begin{array}{l}-0.48 \text { to } \\
+1.89\end{array}$ & - & $\begin{array}{l}-0.66 \text { to } \\
+1.70\end{array}$ & $\begin{array}{l}-0.66 \text { to } \\
+1.47\end{array}$ & $\begin{array}{l}-0.56 \\
\text { to }+1.39\end{array}$ \\
\hline \multicolumn{9}{|l|}{ Contact contribution (\%) } \\
\hline $\mathrm{H} \cdots \mathrm{H}$ & 70.2 & 74.7 & 56.7 & 73.3 & - & 78.9 & 67.1 & 76.4 \\
\hline$d_{e}+d_{i}$ & 2.20 & 2.20 & 2.30 & 2.20 & - & 2.30 & 2.0 & 2.25 \\
\hline $\mathrm{H} \cdots \mathrm{O} / \mathrm{O} \cdots \mathrm{H}$ & 9.5 & 8.2 & 20.6 & 8.5 & - & 6.4 & 15.4 & 7.2 \\
\hline$d_{e}+d_{i}$ & 1.75 & 1.80 & 1.75 & 1.95 & - & 1.75 & 1.75 & 1.85 \\
\hline $\mathrm{H} \cdots \mathrm{C} / \mathrm{C} \cdots \mathrm{H}$ & 20.0 & 17.1 & 22.2 & 18.2 & - & 12.8 & 14.3 & 16.3 \\
\hline$d_{e}+d_{i}$ & 2.95 & 3.05 & 2.70 & 2.65 & - & 2.75 & 2.75 & 2.70 \\
\hline $\begin{array}{l}\text { Other contacts with each } \\
\text { contribution less than } 2 \%\end{array}$ & 0.3 & 0.0 & 0.5 & 0.0 & - & 1.9 & 3.2 & 0.1 \\
\hline
\end{tabular}

* The percentage contribution of each contact cannot be determined for compound (5) as the CIF file of (5) does not contain sufficient input for the HS calculation.

\subsection{Powder X-ray Diffraction (PXRD)}

PXRD is carried out to identify crystalline phase purity and to study the effect of different substituent groups on the crystal packing of the dihydro-benzoxazine dimers. Herein, PXRD patterns of the synthesized dihydro-benzoxazine dimers (Figure 5) were collected by using the synchrotron monochromatic X-ray with the photon energy of $12 \mathrm{keV}$. 
It is found that each dihydro-benzoxazine dimer exhibits its unique diffraction pattern, as listed in Table 5. The different compositions of the molecules according to the variation of substituent groups lead to the different space occupations in the crystal packing, even though they possess similar intermolecular hydrogen bonding interactions. Note that the powder XRD data observed herein are well-matched with the calculated patterns derived from the corresponding single-crystal X-ray crystallography, even though the peak intensities are slightly deviated (see Figures S1-S8 in the Supplementary Information). These results indicate that all dihydro-benzoxazine dimers studied in this work are highly crystalline, which may be due to the formation of strong intermolecular $\mathrm{O}-\mathrm{H} \cdots \mathrm{O}$ and intramolecular $\mathrm{O}-\mathrm{H} \cdots \mathrm{N}$ hydrogen bonds.

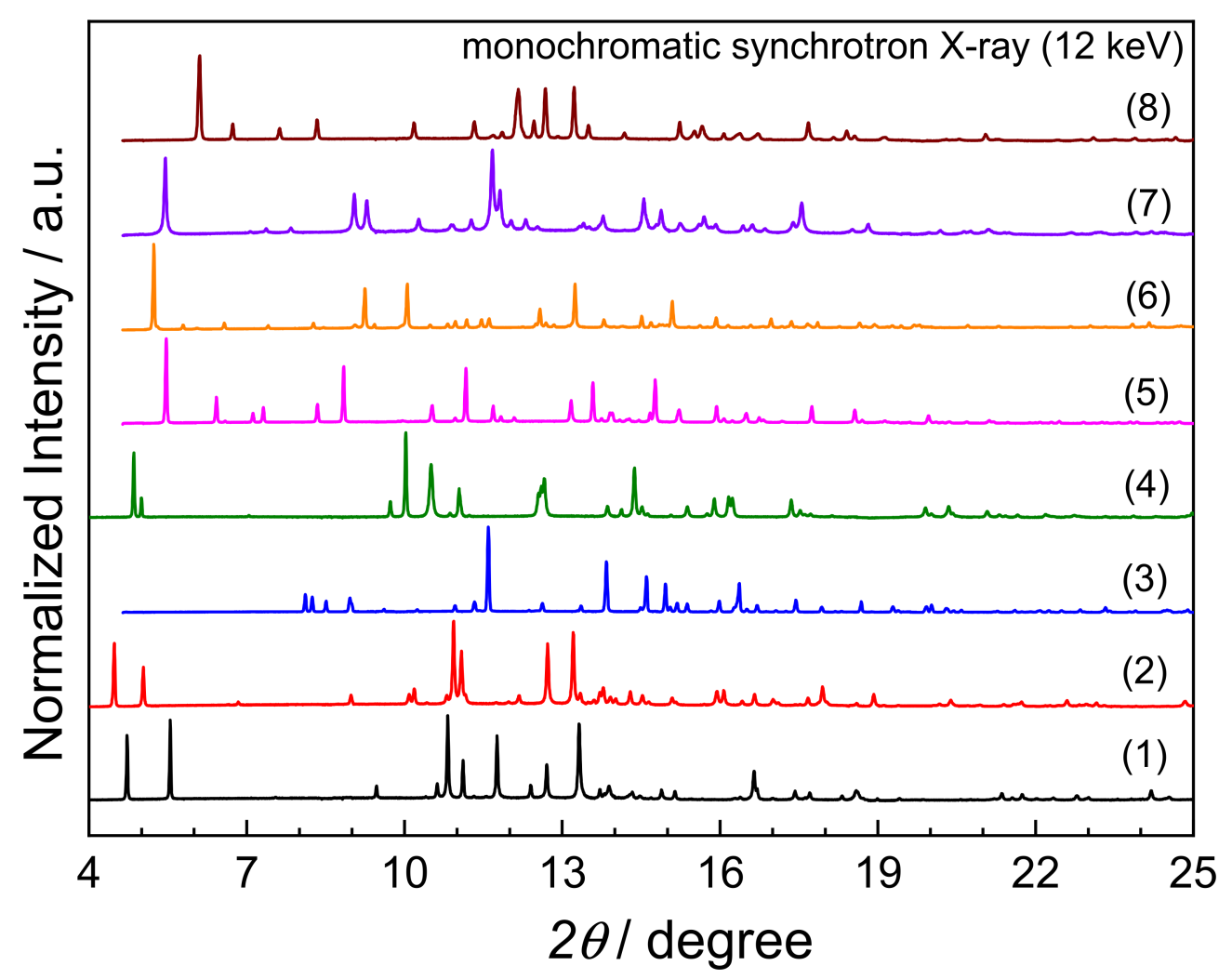

Figure 5. Powder XRD patterns of the dihydro-benzoxazine dimers.

Table 5. Space groups of the dihydro-benzoxazine dimers.

\begin{tabular}{ccccc}
\hline $\begin{array}{c}\text { Dihydro-benzoxazine } \\
\text { Dimer }\end{array}$ & $\begin{array}{c}\text { Space } \\
\text { Group }\end{array}$ & $\begin{array}{c}\text { Measuring } \\
\text { Temperature (K) }\end{array}$ & $\begin{array}{c}\text { CCDC } \\
\text { Number }\end{array}$ & Reference \\
\hline$(1)$ & $\mathrm{P}-1$ & $283-303$ & 613813 & {$[59]$} \\
$(2)$ & $\mathrm{P}-1$ & $283-303$ & 1434969 & {$[60]$} \\
$(3)$ & $\mathrm{P} 2_{1} / \mathrm{c}$ & $283-303$ & 889808 & {$[61]$} \\
$(4)$ & $\mathrm{P}-1$ & $283-303$ & 887033 & {$[62]$} \\
$(5)$ & $\mathrm{C} 2 / \mathrm{c}$ & $283-303$ & 643602 & {$[63]$} \\
$(6)$ & $\mathrm{P}-1$ & $283-303$ & 907527 & {$[64]$} \\
$(7)$ & $\mathrm{P} 2_{1} / \mathrm{n}$ & 298 & 2092708 & This work \\
$(8)$ & $\mathrm{Pna} 2_{1}$ & 100 & 2014264 & {$[65]$} \\
\hline
\end{tabular}

\subsection{Electrochemical Properties of Benzoxazine Dimers}

The use of an aprotic solvent (herein, acetonitrile) to study the electrochemical behavior of dihydro-benzoxazine dimers offers several advantages, including an improvement of their solubility. Moreover, it eliminates or reduces the difficulty related to the chemical reaction coupled with multi-step electron transfers. The CV measurement of the dihydro- 
benzoxazine dimers in acetonitrile also allows the wide range of potential to be measured without interference from the redox reaction of the solvent. The obtained cyclic voltammograms are shown in Figure 6 (and also in Figures S9-S14), while the corresponding electrochemical potentials of the oxidation-reduction processes are listed in Table 6. Only one oxidation peak is found in the dihydro-benzoxazine dimers with the alkyl substituents, namely 4-methyl, 4-ethyl, and 2,4-dimethyl (or the compounds (1), (2), (4), (5), (6), and (8)). For the dihydro-benzoxazine dimers (3) and (7) having the methoxy $\left(-\mathrm{OCH}_{3}\right)$ group at the para-position with respect to the -OH group, two oxidation peaks are recognized. The first oxidation peak, found in all the dihydro-benzoxazine dimers in this work, can be assigned to the oxidation of the hydroxy group. The second oxidation peak is detected in only the dihydro-benzoxazine dimers (3) and (7). Therefore, it is likely associated with the oxidation of the methoxy group, which takes place at potentials above $1 \mathrm{~V}$, in agreement with previous studies [75].

According to the oxidation potentials of different dihydro-benzoxazine dimers, it is clearly seen that the oxidation potentials depend on the substituent groups on both the ortho- and para- positions. The first oxidation potentials for the dihydro-benzoxazine dimers follow the order of $(7)<(3)<(8)<(4)=(6)<(5)=(2)<(1)$. To interpret this trend, the mechanism in Figure 7 is proposed to explain the first oxidation of the dihydrobenzoxazine dimers. Specifically, the first oxidation peak is ascribed to the oxidation of the hydroxy group, leading to the formation of phenoxonium ions as positively charged intermediates [76]. Firstly, an electron and a hydrogen ion are removed from the hydroxy group forming a phenoxy radical $[76,77]$, then the additional electron loss takes place, yielding the phenoxonium ion. The phenoxonium cation is stabilized by delocalizing its positive charge throughout the $\pi$-electron system [78].

Different substituents have different effects on stabilizing the cationic intermediate, and therefore shift the oxidation potential. The dihydro-benzoxazine dimers with the methoxy groups show the greatest shift towards less positive potentials, meaning that the methoxy groups facilitate the oxidation of the hydroxy group. The interpretation is that the methoxy group can enhance the stabilization of the positive charge by a resonance effect since the lone pair of electrons on the methoxy oxygen is donating to the benzene ring, while other substituents cannot cause this resonance stabilization. However, the alkyl substituents (4-methyl, 4-ethyl, and 2,4-dimethyl) can also stabilize the positive charge by an inductive effect. Among the alkyl substituents, 2,4-dimethyl groups can stabilize the cationic intermediates more than the ethyl and the methyl substituents since the positive charge is mainly distributed in the 2 nd and the 4 th positions of the phenyl ring with respect to the $-\mathrm{OH}$ group. Therefore, the oxidation potentials of (4) and (8) are less positive than those of (1), (2), (5), and (6). The methyl and ethyl groups seem to exert a similar inductive effect, as seen from the equal oxidation potentials between (2) and (5). Apart from the substituents on the benzene rings, the substituents on the tertiary $\mathrm{N}$-atom can also help explain the oxidation potential trend. Having a bulkier cyclohexyl group results in a lower oxidation potential than having a methyl group.

Reduction peaks are also observed in the cyclic voltammograms of all the dihydrobenzoxazine dimers. The reduction peak potentials range from -1.47 to $-1.67 \mathrm{~V}$, suggesting that the reduction process for the dihydro-benzoxazine dimers is likely to be irreversible [79]. The reason for the irreversible character of the oxidized products might be due to the possibility to undergo further reactions, such as coupling, proton loss, and/or nucleophilic attack $[76,77,80]$. Hence, our work demonstrates that the substituents on the phenyl and the tertiary-amine moieties have an impact on the oxidation potentials due to their different abilities to stabilize the cationic intermediates. 
(a)

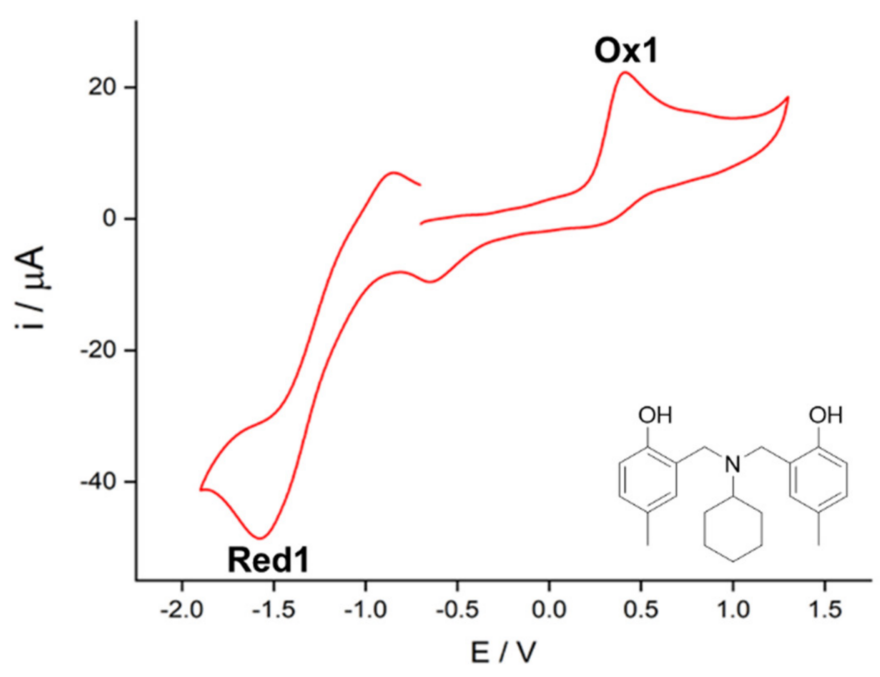

(b)

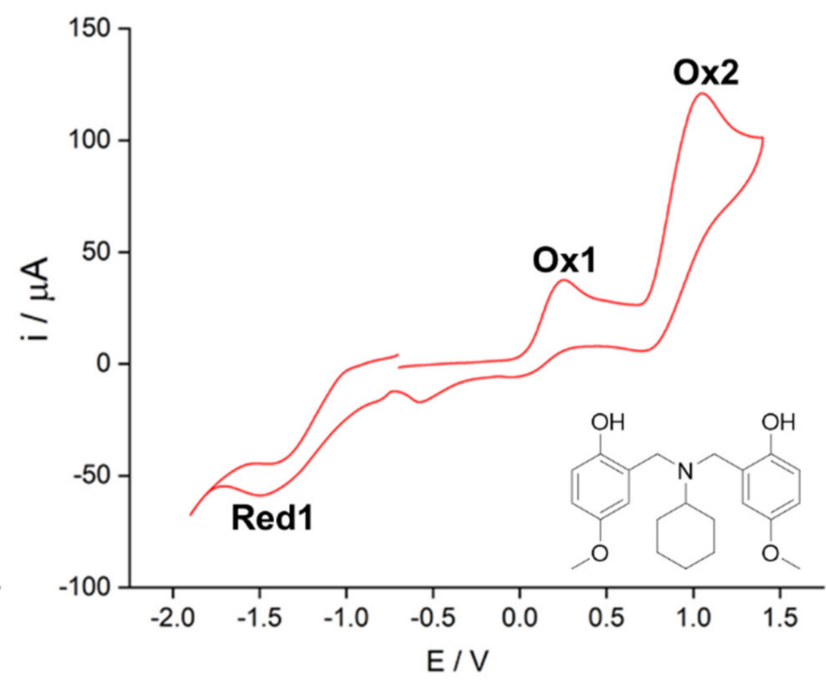

Figure 6. Cyclic voltammograms of (a) the dihydro-benzoxazine dimer (5) and (b) the dihydro-benzoxazine dimer (7) in $\mathrm{ACN}$ containing $\mathrm{TBAPF}_{6}$ as an electrolyte at the scan rate of $100 \mathrm{mV} \mathrm{s}^{-1}$.

Table 6. List of the reduction and the oxidation peak potentials of the dihydro-benzoxazine dimers derived from cyclic voltammetry.

\begin{tabular}{cccc}
\hline $\begin{array}{c}\text { Dihydro-benzoxazine } \\
\text { Dimer }\end{array}$ & $\begin{array}{c}\text { Reduction Peak } \\
\text { Potential (V) }\end{array}$ & $\begin{array}{c}\text { First Oxidation } \\
\text { Peak Potential (V) }\end{array}$ & $\begin{array}{c}\text { Second Oxidation } \\
\text { Peak Potential (V) }\end{array}$ \\
\hline$(1)$ & -1.67 & 0.47 & - \\
$(2)$ & -1.59 & 0.41 & - \\
$(3)$ & -1.52 & 0.33 & -19 \\
$(4)$ & -1.59 & 0.39 & - \\
$(5)$ & -1.59 & 0.41 & - \\
$(6)$ & -1.47 & 0.39 & 1.05 \\
$(7)$ & -1.50 & 0.25 & - \\
\hline
\end{tabular}<smiles>[R]c1cc([R])c(O)c(CN([R3])[R]#C[C-][CH+]C)c1</smiles><smiles>[R]c1cc([R])c(O)c(C)c1</smiles><smiles></smiles>

Phenoxonium intermediates

Figure 7. Proposed mechanism for the first oxidation of the dihydro-benzoxazine dimers. 


\subsection{Computational Study}

DFT calculations were carried out to determine the bandgaps of the dihydrobenzoxazine dimer derivatives in both vacuum and acetonitrile. The calculated bandgaps of the eight derivatives of the dihydro-benzoxazine dimers (Table 7) are around $5 \mathrm{eV}$. Different substituents altered the bandgap energies. It was clearly seen that the dihydrobenzoxazine dimers possessing the methoxy substituent groups, herein compounds (3) and (7), have the lowest bandgaps among others in both the calculations in a vacuum and in acetonitrile.

The frontier molecular orbitals (HOMO and LUMO) of the optimized structures of the eight dihydro-benzoxazine dimer derivatives were visualized with the VESTA program using the isosurface of 0.02 (as shown in Table 8). Note that the optimized structures possess one of the $-\mathrm{OH}$ substituent of the phenolate moieties pointing towards the $\mathrm{N}$ amine center in a similar fashion to the one observed from the X-ray crystallographic data. These observations confirm the possibility of forming the intermolecular hydrogen bond of the studied compounds, as discussed previously.

As visualized in Table 8, the obtained HOMO of each dihydro-benzoxazine dimer derivative reveals the contribution of the aza-methylene-phenol moiety, including the substituents on the phenol ring. The relatively higher energy (Hartree) HOMO is observed in both compounds (3) and (7), possessing the methoxy substituent group. In addition, most of the obtained LUMO indicates the major contribution from the phenyl-methyleneaza-methylene-phenyl centered scaffold. In this case, the relatively lower energy (Hartree) LUMO is observed in both compounds (3) and (7), possessing the methoxy substituent group. Combining both the increase of HOMO energy and the decrease of LUMO energy, the electron-donating methoxy substituents exhibit the effect of lowering the bandgap of the dihydro-benzoxazine dimer derivatives, as the methoxy groups have lone pairs of electrons that can delocalize towards the benzene rings. These DFT results are firmly in line with the electrochemical study. Overall, the computational results reveal the effects of the substituents on the electronic and electrochemical properties of the dihydro-benzoxazine dimer derivatives.

Table 7. Calculated HOMOs, LUMOs, and bandgap energies of the dihydro-benzoxazine dimers in vacuum and acetonitrile.

\begin{tabular}{ccccccc}
\hline \multirow{2}{*}{\begin{tabular}{c} 
Dihydro-benzoxazine $\begin{array}{c}\text { In Vacuum } \\
\text { Dimer }\end{array}$ \\
\cline { 2 - 7 }
\end{tabular}} & $\begin{array}{c}\text { HOMO } \\
\text { (Hartree) }\end{array}$ & $\begin{array}{c}\text { LUMO } \\
\text { (Hartree) }\end{array}$ & $\begin{array}{c}\text { Bandgap } \\
\mathbf{( e V )}\end{array}$ & $\begin{array}{c}\text { HOMO } \\
\text { (Hartree) }\end{array}$ & $\begin{array}{c}\text { LUMO } \\
\text { (Hartree) }\end{array}$ & $\begin{array}{c}\text { Bandgap } \\
(\mathbf{e V})\end{array}$ \\
\hline$(1)$ & -0.20818 & -0.02709 & 4.93 & -0.22056 & -0.02685 & 5.27 \\
$(2)$ & -0.20871 & -0.02642 & 4.96 & -0.22085 & -0.02612 & 5.30 \\
$(3)$ & -0.19663 & -0.02850 & 4.58 & -0.20990 & -0.02959 & 4.91 \\
$(4)$ & -0.20359 & -0.02205 & 4.94 & -0.21691 & -0.02321 & 5.27 \\
$(5)$ & -0.20685 & -0.02395 & 4.98 & -0.21975 & -0.02522 & 5.29 \\
$(6)$ & -0.20675 & -0.02281 & 5.01 & -0.21926 & -0.02357 & 5.32 \\
$(7)$ & -0.19486 & -0.02508 & 4.62 & -0.20871 & -0.02709 & 4.94 \\
$(8)$ & -0.20815 & -0.02120 & 5.09 & -0.21694 & -0.02468 & 5.23 \\
\hline
\end{tabular}


Table 8. Visualization of the HOMO and LUMO of the dihydro-benzoxazine dimers (1) to (8) in acetonitrile. The isosurface is 0.02 .

\begin{tabular}{|c|c|c|}
\hline Compound & HOMO & LUMO \\
\hline (1) & & \\
\hline (2) & & \\
\hline (3) & & \\
\hline$(4)$ & & \\
\hline (5) & & \\
\hline (6) & & \\
\hline (7) & & \\
\hline (8) & & \\
\hline
\end{tabular}




\section{Conclusions}

Eight dihydro-benzoxazine dimer derivatives possessing four different substituent groups on the phenyl rings with two different substituents at the tertiary-amine nitrogen were successfully synthesized. The crystal structure of (7) is reported herein for the first time and consequently correlates with the other dihydro-benzoxazine dimers for better understanding. According to the refined crystallographic data and the Hirshfeld surface analysis, the hydrogen bonding interactions play a crucial role in the crystal packing of dihydro-benzoxazine dimers. Interestingly, the intermolecular $\mathrm{O}-\mathrm{H} \cdots \mathrm{O}$ hydrogen bonds linked to inversion-related molecules with the $R_{2}{ }^{2}(20)$ motif are commonly found to be the major interactions responsible for crystal packing of the dihydro-benzoxazine dimers. The increase of the steric effect of the substituent groups, such as in the case of compound (8), may lead to the formation of the $C(10)$ hydrogen bond chain instead. A variety of chemical functionalities of the substituents leads to a variation of crystal space group and unit cell parameters referring to the unique PXRD data of each compound. Moreover, the different substituent groups induce the characteristic electrochemical behavior of each compound. The first oxidation peak represents the oxidation of the phenolic $-\mathrm{OH}$ group and is varied in the range from 0.25 to $0.47 \mathrm{eV}$ depending on the ability of the substituents to stabilize the phenoxonium cation intermediate via electron donation and/or induction. Combining the better electron-donating behavior of both the para-methoxy group and the N-substituted cyclohexyl group, (7) reveals the lowest oxidative potential among the others. The decrease of DFT-calculated bandgaps is observed in a similar fashion as the electrochemical behavior monitoring by cyclic voltammetry, which highlights the effect of a variety of substituents. This work significantly indicates the influence of chemical functionalities on crystal structures and electrochemical properties of dihydro-benzoxazine dimer derivatives, which could provide the perspectives towards understanding their redox nature and chelating properties used for metal-organic complex formation. A comprehensive investigation will be undertaken in future work.

Supplementary Materials: The following are available online at https:/ / www.mdpi.com/article/10 $.3390 /$ cryst11080979/s1, Figures S1-S14.

Author Contributions: Conceptualization, W.W.; data curation, S.W., W.W.; formal analysis, S.W., W.W.; funding acquisition, W.W.; investigation, N.S., K.C., S.I., P.P., V.B., R.B.-R., S.L., Y.H., S.W., W.W.; methodology, S.W., W.W.; project administration, S.W., W.W.; resources, K.C., S.I., P.P., S.L., P.K., Y.H., S.W., W.W.; software, S.I., V.B., R.B.-R.; supervision, W.W.; validation, S.W., W.W.; visualization, S.W., W.W.; writing—original draft, N.S., S.W., W.W.; Writing—review \& editing, K.C., S.I., V.B., P.K., S.W., W.W. All authors have read and agreed to the published version of the manuscript.

Funding: This research received no external funding.

Data Availability Statement: The data presented in this study are available within the article and in Supplementary Materials.

Acknowledgments: The Department of Materials Engineering, Faculty of Engineering, Kasetsart University, National Nanotechnology Center, National Science and Technology Development Agency, and the School of Chemistry, Institute of Science, Suranaree University of Technology are acknowledged for the support of the facilities. We acknowledge the Synchrotron Light Research Institute (Public Organization), SLRI, Thailand, for the provision of beamtime for XRD at BL1.1W. All research staff of BL1.1W are acknowledged for their assistance during the experiments. We thank the Nanoscale Simulation Laboratory at National Nanotechnology Center (NANOTEC) for providing computational resource.

Conflicts of Interest: The authors declare no conflict of interest.

\section{References}

1. Ishida, H.; Agag, T. Handbook of Benzoxazine Resins; Elsevier: Amsterdam, The Netherlands; Boston, MA, USA, 2011.

2. Kiskan, B.; Ghosh, N.N.; Yagci, Y. Polybenzoxazine-Based Composites as High-Performance Materials. Polym. Int. 2011, 60, 167-177. [CrossRef] 
3. Ghosh, N.N.; Kiskan, B.; Yagci, Y. Polybenzoxazines-New high performance thermosetting resins: Synthesis and properties. Prog. Polym. Sci. 2007, 32, 1344-1391. [CrossRef]

4. Yagci, Y.; Kiskan, B.; Ghosh, N.N. Recent advancement on polybenzoxazine-A newly developed high performance thermoset. J. Polym. Sci. Part A Polym. Chem. 2009, 47, 5565-5576. [CrossRef]

5. Rimdusit, S.; Tiptipakorn, S.; Jubsilp, C.; Takeichi, T. Polybenzoxazine alloys and blends: Some unique properties and applications. React. Funct. Polym. 2013, 73, 369-380. [CrossRef]

6. Demir, K.D.; Kiskan, B.; Aydogan, B.; Yagci, Y. Thermally curable main-chain benzoxazine prepolymers via polycondensation route. React. Funct. Polym. 2013, 73, 346-359. [CrossRef]

7. Kim, H.-D.; Ishida, H. Study on the Chemical Stability of Benzoxazine-Based Phenolic Resins in Carboxylic Acids. Appl. Polym. Sci. 2001, 79, 1207-1219. [CrossRef]

8. Shen, S.B.; Ishida, H. Development and Characterization of High-Performance Polybenzoxazine Composites. Polym. Compos. 1996, 17, 710-719. [CrossRef]

9. Xu, Y.; Li, P.; Li, L.; Dai, J.; Ran, Q.; Gu, Y. Thermal degradation mechanism of a cured acetylene/aldehyde functional benzoxazine with high thermal stability. Polym. Degrad. Stab. 2020, 171, 109041. [CrossRef]

10. Liao, Y.-T.; Lin, Y.-C.; Kuo, S.-W. Highly Thermally Stable, Transparent, and Flexible Polybenzoxazine Nanocomposites by Combination of Double-Decker-Shaped Polyhedral Silsesquioxanes and Polydimethylsiloxane. Macromolecules 2017, 50, 5739-5747. [CrossRef]

11. Ran, Q.-C.; Zhang, D.-X.; Zhu, R.-Q.; Gu, Y. The structural transformation during polymerization of benzoxazine/ $\mathrm{FeCl}_{3}$ and the effect on the thermal stability. Polymer 2012, 53, 4119-4127. [CrossRef]

12. Zhang, K.; Liu, J.; Ohashi, S.; Liu, X.; Han, Z.; Ishida, H. Synthesis of high thermal stability polybenzoxazoles via ortho-imidefunctional benzoxazine monomers. J. Polym. Sci. Part A Polym. Chem. 2015, 53, 1330-1338. [CrossRef]

13. El-Mahdy, A.F.M.; Kuo, S.-W. Direct synthesis of poly(benzoxazine imide) from an ortho-benzoxazine: Its thermal conversion to highly cross-linked polybenzoxazole and blending with poly(4-vinylphenol). Polym. Chem. 2018, 9, 1815-1826. [CrossRef]

14. Pei, L.; Zhao, S.; Li, H.; Zhang, X.; Fan, X.; Wang, W.; Zhang, C.; Zhao, G.; Wang, Z. Preparation of low temperature cure polybenzoxazine coating with enhanced thermal stability and mechanical properties by combustion synthesis approach. Polymer 2021, 220, 123573. [CrossRef]

15. Chen, C.-H.; Lin, C.-H.; Hon, J.-M.; Wang, M.-W.; Juang, T.-Y. First halogen and phosphorus-free, flame-retardant benzoxazine thermosets derived from main-chain type bishydroxydeoxybenzoin-based benzoxazine polymers. Polymer 2018, $154,35-41$. [CrossRef]

16. Nair, C. Advances in addition-cure phenolic resins. Prog. Polym. Sci. 2004, 29, 401-498. [CrossRef]

17. Lin, C.H.; Cai, S.X.; Leu, T.S.; Hwang, T.Y.; Lee, H.H. Synthesis and properties of flame-retardant benzoxazines by three approaches. J. Polym. Sci. Part A Polym. Chem. 2006, 44, 3454-3468. [CrossRef]

18. Ishida, H.; Allen, D.J. Physical and Mechanical Characterization of Near-Zero Shrinkage Polybenzoxazines. Polym. Sci. Part B Polym. Phys. 1996, 34, 1019-1030. [CrossRef]

19. Zhang, K.; Han, L.; Froimowicz, P.; Ishida, H. A Smart Latent Catalyst Containingo-Trifluoroacetamide Functional Benzoxazine: Precursor for Low Temperature Formation of Very High Performance Polybenzoxazole with Low Dielectric Constant and High Thermal Stability. Macromolecules 2017, 50, 6552-6560. [CrossRef]

20. Wu, J.; Xi, Y.; McCandless, G.T.; Xie, Y.; Menon, R.; Patel, Y.; Yang, D.J.; Iacono, S.T.; Novak, B.M. Synthesis and Characterization of Partially Fluorinated Polybenzoxazine Resins Utilizing Octafluorocyclopentene as a Versatile Building Block. Macromolecules 2015, 48, 6087-6095. [CrossRef]

21. Chen, K.-C.; Li, H.-T.; Huang, S.-C.; Chen, W.-B.; Sun, K.-W.; Chang, F.-C. Synthesis and performance enhancement of novel polybenzoxazines with low surface free energy. Polym. Int. 2011, 60, 1089-1096. [CrossRef]

22. Zhang, K.; Yu, X.; Kuo, S.-W. Outstanding dielectric and thermal properties of main chain-type poly(benzoxazine-co-imide-cosiloxane)-based cross-linked networks. Polym. Chem. 2019, 10, 2387-2396. [CrossRef]

23. Cao, Y.; Chen, C.; Lu, X.; Xu, D.; Huang, J.; Xin, Z. Bio-based polybenzoxazine superhydrophobic coating with active corrosion resistance for carbon steel protection. Surf. Coat. Technol. 2021, 405, 126569. [CrossRef]

24. Chen, C.; Cao, Y.; Lu, X.; Li, X.; Yao, H.; Xin, Z. Copolymer of eugenol-based and pyrogallol-based benzoxazines: Low curing temperature and enhanced corrosion resistance. Colloids Surf. A Physicochem. Eng. Asp. 2021, 609, 125605. [CrossRef]

25. Zachariah, S.; Liu, Y.-L. Nanocomposites of polybenzoxazine-functionalized multiwalled carbon nanotubes and polybenzoxazine for anticorrosion application. Compos. Sci. Technol. 2020, 194, 108169. [CrossRef]

26. Aly, K.I.; Mohamed, M.G.; Younis, O.; Mahross, M.H.; Abdel-Hakim, M.; Sayed, M.M. Salicylaldehyde azine-functionalized polybenzoxazine: Synthesis, characterization, and its nanocomposites as coatings for inhibiting the mild steel corrosion. Prog. Organ. Coat. 2020, 138, 105385. [CrossRef]

27. Mohamed, M.G.; Kuo, S.W.; Mahdy, A.; Ghayd, I.M.; Aly, K.I. Bisbenzylidene cyclopentanone and cyclohexanone-functionalized polybenzoxazine nanocomposites: Synthesis, characterization, and use for corrosion protection on mild steel. Mater. Today Commun. 2020, 25, 101418. [CrossRef]

28. Xu, D.; Lou, C.; Huang, J.; Lu, X.; Xin, Z.; Zhou, C. Effect of inhibitor-loaded halloysite nanotubes on active corrosion protection of polybenzoxazine coatings on mild steel. Prog. Organ. Coat. 2019, 134, 126-133. [CrossRef] 
29. Chirachanchai, S.; Laobuthee, A.; Phongtamrug, S. Self termination of ring opening reaction ofp-substituted phenol-based benzoxazines: An obstructive effectviaintramolecular hydrogen bond. J. Heterocycl. Chem. 2009, 46, 714-721. [CrossRef]

30. Hemvichian, K.; Laobuthee, A.; Chirachanchai, S.; Ishida, H. Thermal decomposition processes in polybenzoxazine model dimers investigated by TGA-FTIR and GC-MS. Polym. Degrad. Stab. 2002, 76, 1-15. [CrossRef]

31. Dayo, A.Q.; Gao, B.-C.; Wang, J.; Liu, W.-B.; Derradji, M.; Shah, A.H.; Babar, A.A. Natural hemp fiber reinforced polybenzoxazine composites: Curing behavior, mechanical and thermal properties. Compos. Sci. Technol. 2017, 144, 114-124. [CrossRef]

32. Kajohnchaiyagual, J.; Jubsilp, C.; Dueramae, I.; Rimdusit, S. Thermal and mechanical properties enhancement obtained in highly filled alumina-polybenzoxazine composites. Polym. Compos. 2014, 35, 2269-2279. [CrossRef]

33. Li, N.; Yan, H.; Xia, L.; Mao, L.; Fang, Z.; Song, Y.; Wang, H. Flame retarding and reinforcing modification of ramie/polybenzoxazine composites by surface treatment of ramie fabric. Compos. Sci. Technol. 2015, 121, 82-88. [CrossRef]

34. Laobuthee, A.; Ishida, H.; Chirachanchai, S. Metal Ion Guest Responsive Benzoxazine Dimers and Inclusion Phenomena of Cyclic Derivatives. Inclus. Phenom. Macrocycl. Chem. 2003, 47, 179-185. [CrossRef]

35. Rungsimanon, T.; Laobuthee, A.; Miyata, M.; Chirachanchai, S. Guest entrapment via type and size of dibenzo-monoaza-crownsbased N,N-bis(alkyl-2-hydroxybenzyl)alkylamine host. Chem. Lett. 2008, 37, 1108-1109. [CrossRef]

36. Sutapin, C.; Mantaranon, N.; Chirachanchai, S. Eight-armed polydiacetylene under benzoxazine dimer branched polylactide: A structural combination for reversible thermochromic effects and a model case for free-standing poly(lactic acid) films. J. Mater. Chem. C 2017, 5, 8288-8294. [CrossRef]

37. Sriratanasak, N.; Nonpanya, N.; Wattanathana, W.; Chanvorachote, P. Benzoxazine dimer analogue targets integrin $\beta 3$ in lung cancer cells and suppresses anoikis resistance and migration. Anticancer Res. 2020, 40, 2583-2589. [CrossRef]

38. Sriratanasak, N.; Petsri, K.; Laobuthee, A.; Wattanathana, W.; Vinayanuwattikun, C.; Luanpitpong, S.; Chanvorachote, P. Novel c-Myc-targeting compound N, N-Bis (5-ethyl-2-hydroxybenzyl) methylamine for mediated c-Myc ubiquitin-proteasomal degradation in lung cancer cells. Mol. Pharmacol. 2020, 98, 130-142. [CrossRef]

39. Iguchi, D.; Salum, M.L.; Froimowicz, P. Application of Benzoxazine-Based Dimers, Oligomers and Polymers as Chelating Agents. Macromol. Chem. Phys. 2019, 220, 1800366. [CrossRef]

40. Veranitisagul, C.; Kaewvilai, A.; Sangngern, S.; Wattanathana, W.; Suramitr, S.; Koonsaeng, N.; Laobuthee, A. Novel recovery of nano-structured ceria $\left(\mathrm{CeO}_{2}\right)$ from $\mathrm{Ce}(\mathrm{III})$-benzoxazine dimer complexes via thermal decomposition. Int. J. Mol. Sci. 2011, 12, 4365-4377. [CrossRef]

41. Fujita, K.-I.; Kawahara, R.; Aikawa, T.; Yamaguchi, R. Hydrogen Production from a Methanol-Water Solution Catalyzed by an Anionic Iridium Complex Bearing a Functional Bipyridonate Ligand under Weakly Basic Conditions. Angew. Chem. Int. Ed. Engl. 2015, 54, 9057-9060. [CrossRef]

42. Finn, M.; Ridenour, J.A.; Heltzel, J.; Cahill, C.; Voutchkova-Kostal, A. Next-Generation Water-Soluble Homogeneous Catalysts for Conversion of Glycerol to Lactic Acid. Organometallics 2018, 37, 1400-1409. [CrossRef]

43. Liu, J.-F.; Zhao, Z.-S.; Jiang, G.-B. Coating $\mathrm{Fe}_{3} \mathrm{O}_{4}$ Magnetic Nanoparticles with Humic Acid for High Efficient Removal of Heavy Metals in Wate. Environ. Sci. Technol. 2008, 42, 6949-6954. [CrossRef]

44. Li, L.; Yuan, F.; Li, T.; Zhou, Y.; Zhang, M. Synthesis and crystal structures of cerium(IV) complexes with 8-quinolinolate and amine bis(phenolate) ligands. Inorgan. Chim. Acta 2013, 397, 69-74. [CrossRef]

45. Ma, Z.; Moulton, B. Recent advances of discrete coordination complexes and coordination polymers in drug delivery. Coord. Chem. Rev. 2011, 255, 1623-1641. [CrossRef]

46. Sun, R.W.-Y.; Ma, D.-L.; Wong, E.L.-M.; Che, C.-M. Some uses of transition metal complexes as anti-cancer and anti-HIV agents. Dalton Trans. 2007, 43, 4884-4892.

47. Maketon, W.; Zenner, C.Z.; Ogden, K.L. Removal Efficiency and Binding Mechanisms of Copper and Copper-EDTA Complexes Using Polyethyleneimine. Environ. Sci. Technol. 2008, 42, 2124-2129. [CrossRef] [PubMed]

48. Wattanathana, W.; Nonthaglin, S.; Veranitisagul, C.; Koonsaeng, N.; Laobuthee, A. Crystal structure and novel solid-state fluorescence behavior of the model benzoxazine monomer: 3,4-Dihydro-3,6-dimethyl-1,3,2H-benzoxazine. J. Mol. Struct. 2014, 1074, 118-125. [CrossRef]

49. Kaewvilai, A.; Rujitanapanich, S.; Wattanathana, W.; Veranitisagul, C.; Suramitr, S.; Koonsaeng, N.; Laobuthee, A. The effect of alkali and Ce(III) ions on the response properties of benzoxazine supramolecules prepared via molecular assembly. Molecules 2012, 17, 511-526. [CrossRef]

50. Wattanathana, W.; Hanlumyuang, Y.; Wannapaiboon, S.; Chansaenpak, K.; Pinyou, P.; Nanok, T.; Kanjanaboos, P. Novel Dihydro1,3,2H-benzoxazine Derived from Furfurylamine: Crystal Structure, Hirshfeld Surface Analysis, Photophysical Property, and Computational Study. Crystals 2021, 11, 568. [CrossRef]

51. SAINT Version 8.34A 2013; Bruker AXS: Madison, WI, USA, 2013.

52. Sheldrick, G.M. SADABS; University of Gottingen: Gottingen, Germany, 1996.

53. Dolomanov, O.V.; Bourhis, L.J.; Gildea, R.J.; Howard, J.A.K.; Puschmann, H. OLEX2: A complete structure solution, refinement and analysis program. J. Appl. Crystallogr. 2009, 42, 339-341. [CrossRef]

54. Sheldrick, G.M. SHELXT—Integrated space-group and crystal-structure determination. Acta Crystallogr. A Found. Adv. 2015, 71, 3-8. [CrossRef] [PubMed]

55. Sheldrick, G.M. Crystal structure refinement with SHELXL. Acta Crystallogr. C Struct. Chem. 2015, 71, 3-8. [CrossRef] [PubMed] 
56. Macrae, C.F.; Edgington, P.R.; McCabe, P.; Pidcock, E.; Shields, G.P.; Taylor, R.; Towler, M.; Streek, J. Mercury: Visualization and analysis of crystal structures. J. Appl. Crystallogr. 2006, 39, 453-457. [CrossRef]

57. Cossi, M.; Barone, V. Analytical second derivatives of the free energy in solution by polarizable continuum models. J. Chem. Phys. 1998, 109, 6246-6254. [CrossRef]

58. Frisch, M.J.; Trucks, G.W.; Schlegel, H.B.; Scuseria, G.E.; Robb, M.A.; Cheeseman, J.R.; Scalmani, G.; Barone, V.; Petersson, G.A.; Nakatsuji, H.; et al. Gaussian 09, Revision D.01; Gaussian, Inc.: Wallingford, CT, USA, 2013.

59. Wu, M.-H.; Liu, W.-J.; Zou, W.-D.; Wang, H.-Y. 4,4'-Dimethyl-2,2'-(N-methyliminodimethylene)-diphenol. Acta Crystallogr. Sect. E 2006, 62, o2949-o2950. [CrossRef]

60. Wattanathana, W.; Nootsuwan, N.; Veranitisagul, C.; Koonsaeng, N.; Suramitr, S. Crystallographic, spectroscopic (FT-IR/FTRaman) and computational (DFT/B3LYP) studies on 4,4'-diethyl-2,2'-[methylazanediylbis(methylene)]diphenol. J. Mol. Struct. 2016, 1109, 201-208. [CrossRef]

61. Veranitisagul, C.; Kaewvilai, A.; Duangthongyou, T.; Koonsaeng, N.; Laobuthee, A. 4,4'-Dimethoxy-2,2'-[methylazanediylbis (methylene)]diphenol. Acta Crystallogr. Sect. E Struct. Rep. Online 2012, 68, o2139. [CrossRef] [PubMed]

62. Veranitisagul, C.; Wattanathana, W.; Kaewvilai, A.; Duangthongyou, T.; Laobuthee, A.; Koonsaeng, N. 2-\{[(2-Hydroxy-3,5dimethylbenzyl)(methyl)amino]-methyl\}-4,6-dimethylphenol. Acta Crystallogr. Sect. E Struct. Rep. Online 2012, 68, o1826. [CrossRef] [PubMed]

63. Phongtamrug, S.; Tashiro, K.; Miyata, M.; Chirachanchai, S. Supramolecular Structure of N,N-Bis(2-hydroxybenzyl alkylamine: Flexible Molecular Assembly Framework for Host without Guest and Host with Guest. Phys. Chem. B 2006, 110, 21365-21370. [CrossRef]

64. Wattanathana, W.; Veranitisagul, C.; Kaewvilai, A.; Laobuthee, A.; Koonsaeng, N. 4,4'-Diethyl-2,2'-[(N-cyclohexylimino) bis(methylene)]diphenol. Acta Crystallogr. Sect. E 2012, 68, o3050. [CrossRef]

65. Wannapaiboon, S.; Hanlumyuang, Y.; Chansaenpak, K.; Pinyou, P.; Veranitisagul, C.; Laobuthee, A.; Wattanathana, W. Crystal structure and Hirshfeld surface analysis of the product of the ring-opening reaction of a dihydrobenzoxazine: 6,6 ' [(cyclohexylazanediyl)bis(methylene)]bis(2,4-dimethylphenol). Acta Crystallogr. Sect. E 2020, 76, 1239-1244. [CrossRef]

66. Etter, M.C.; MacDonald, J.C.; Bernstein, J. Graph-Set Analysis of Hydrogen-Bond Patterns in Organic Crystals. Acta Crystallogr. Sect. B Struct. Sci. 1990, 46, 256-262. [CrossRef]

67. Bernstein, J.; Shimoni, L.; Davis, R.E.; Chang, N.-L. Graph set analysis of hydrogen-bond patterns in organic crystals. Recent developments and applications. Acta Crystallogr. Sect. A Found. Crystallogr. 1993, 49, c164. [CrossRef]

68. Grell, J.; Bernstein, J.; Tinhofer, G. Graph-set analysis of hydrogen-bond patterns: Some mathematical concepts. Acta Crystallogr. Sect. B Struct. Sci. 1999, 55, 1030-1043. [CrossRef]

69. Suramitr, S.; Teanwarawat, J.; Ithiapa, N.; Wattanathana, W.; Suramitr, A. Crystal structure, Hirshfeld surface analysis and computational study of a rhodamine B salicylaldehyde Schiff base derivative. Acta Crystallogr. E Crystallogr. Commun. 2020, 76, 1027-1032. [CrossRef]

70. Froimowicz, P.; Zhang, K.; Ishida, H. Intramolecular Hydrogen Bonding in Benzoxazines: When Structural Design Becomes Functional. Chemistry 2016, 22, 2691-2707. [CrossRef] [PubMed]

71. Hirshfeld, F.L. Bonded-atom fragments for describing molecular charge densities. Theor. Chim. Acta 1977, 44, 129-138. [CrossRef]

72. Spackman, M.A.; Jayatilakaa, D. Hirshfeld surface analysis. CrystEngComm 2009, 11, 19-32. [CrossRef]

73. Turner, M.J.; McKinnon, J.J.; Wolff, S.K.; Grimwood, D.J.; Spackman, P.R.; Jayatilaka, D.; Spackman, M.A. Crystal Explorer. Version 17; University of Western Australia: Crawley, Australia, 2017.

74. McKinnon, J.J.; Jayatilaka, D.; Spackman, M.A. Towards quantitative analysis of intermolecular interactions with Hirshfeld surfaces. Chem. Commun. 2007, 3814-3816. [CrossRef] [PubMed]

75. Roth, H.G.; Romero, N.A.; Nicewicz, D.A. Experimental and Calculated Electrochemical Potentials of Common Organic Molecules for Applications to Single-Electron Redox Chemistry. Synlett 2015, 27, 714-723.

76. Ferreira, M.; Varela, H.; Torresi, R.M.; Tremiliosi-Filho, G. Electrode passivation caused by polymerization of different phenolic compounds. Electrochim. Acta 2006, 52, 434-442. [CrossRef]

77. Hammerich, O.; Speiser, B. Organic Electrochemistry, 4th ed.; Marcel Dekker: New York, NY, USA, 2016 ; pp. 150-154.

78. Simić, A.; Manojlović, D.; Šegan, D.; Todorović, M. Electrochemical Behavior and Antioxidant and Prooxidant Activity of Natural Phenolics. Molecules 2007, 12, 2327-2340. [CrossRef] [PubMed]

79. Dean, R.K.; Fowler, C.I.; Hasan, K.; Kerman, K.; Kwong, P.; Trudel, S.; Leznoff, D.B.; Kraatz, H.-B.; Dawee, L.N.; Kozak, C.M. Magnetic, electrochemical and spectroscopic properties of iron(III) amine-bis(phenolate) halide complexes. Dalton Trans. 2012, 41, 4806-4816. [CrossRef] [PubMed]

80. Hotta, H.; Ueda, M.; Nagano, S.; Tsujino, Y.; Koyama, J.; Osakai, T. Mechanistic study of the oxidation of caffeic acid by digital simulation of cyclic voltammograms. Anal. Biochem. 2002, 303, 66-72. [CrossRef] [PubMed] 